\title{
SCIENTIFIC IGNORANCE AND RELIABLE PATTERNS OF EVIDENCE IN TOXIC TORT CAUSATION: IS THERE A NEED FOR LIABILITY REFORM?
}

\author{
CARL F. CRANOR* AND DAVID A. EASTMOND**
}

\section{INTRODUCTION}

The U.S. Supreme Court, urged on by legal scholars, affected industries, a number of lower court decisions, and some in the scientific community, has instituted substantial evidentiary reform of admissibility requirements for scientific evidence in the law. ${ }^{1}$ Evidentiary reform, however, is beginning to pose problems of its own, ${ }^{2}$ and a growing number of scholars are concerned about its impact on tort law. ${ }^{3}$ Courts appear to be struggling to find the right guidance for admitting and excluding evidence. Indeed, it appears that there will be intra- and inter-circuit disagreements about general causation for the same sub-

Copyright (C) 2001 by Carl F. Cranor and David A. Eastmond

This article is also available at http://www.law.duke.edu/journals/64LCPCranor.

* Professor, Department of Philosophy, University of California, Riverside.

** Professor and Chair of the Environmental Toxicology Graduate Program, University of California, Riverside.

A previous version of this paper was discussed at the UCLA Law and Philosophy Discussion Group, the Duke Law School Conference on Causation in Toxic Tort Law, and the University of California, Riverside, Philosophy Department. We are grateful to Greg Keating, Larry Solum, Seana Shiffrin, John Conley, Francis McGovern, Joe Sanders, Larry Solan, and Barbara Spellman, whose comments have helped to improve the paper. This research has been funded by grants from National Science Foundation (\#99-10952), the University of California Toxic Substances Research and Teaching Program, and the University of California, Riverside.

1. Two of the leading cases in this reform effort have been in the field of toxic tort law. See Daubert v. Merrell Dow Pharms., Inc., 509 U.S. 579 (1993); General Elec. Co. v. Joiner, 522 U.S. 136 (1997). In each case, the Court expressed concerns about the scientific quality of the evidence underlying expert testimony. The admissibility of evidence in toxic tort cases is the focus of this article.

2. See Margaret A. Berger, Eliminating General Causation: Notes Towards a New Theory of Justice and Toxic Torts, 97 COLUM. L. REV. 2117 (1997).

3. See id.; see also Margaret A. Berger, The Supreme Court's Trilogy on the Admissibility of Expert Testimony, in FEDERAL REFERENCE MANUAL ON SCIENTIFIC EVIDENCE 9 (Federal Judicial Ctr. ed., 2d ed. 2000); Lucinda M. Finley, Guarding the Gate to the Courthouse: How Trial Judges are Using their Evidentiary Screening Role to Remake Tort Causation Rules, 49 DEPAUL L. REV. 335 (1999); Michael H. Graham, Gatekeeping Test of Daubert, Kumho and Proposed Amended Rule 702 of the Federal Rules of Evidence, 54 U. MiAmI L. REV. 317, 324 (2000); Michael D. Green, The Road Less Well Traveled (and Seen): Contemporary Lawmaking in Products Liability, 49 DEPAUL L. REV. 377 (1999); David Ozonoff, A Fish Out of Water: The Scientist in Court, Paper presented at the National Academy of Sciences Scientific Evidence Workshop (Sept. 6, 2000). 
stance. ${ }^{4}$ Some courts appear to have overreacted to the Supreme Court's gatekeeping mandate and have rejected evidence that was derived by the methods and procedures of science as revealed by scientific practice and highly regarded scientific bodies. Such consequences are not surprising due to the subtle tensions between science and law. Given the tension, then, how should the science/law interaction be addressed in order to retain fidelity to the principal goals and strengths of both fields?

The legal picture is further complicated by the realities of toxicology. In general, little is known about the universe of approximately 100,000 chemical substances or their derivatives registered for commerce (with 800 to 1000 new substances added to the list each year). ${ }^{5}$ Surprisingly, for seventy-five percent of the 3000 top-volume chemicals in commerce, the most basic toxicity results cannot be found in the public record. ${ }^{6}$ Yet these knowledge gaps will be slow to close because both animal and human studies are costly and take years to conduct, interpret, and understand. It takes even longer to develop a scientific consensus about any toxic properties. For a significant subset of these substances, including carcinogens, chronic toxicants, and some reproductive toxicantsthose with long latency periods or associated with erratic exposure patternsthese problems are exacerbated. ${ }^{7}$

Lack of scientific knowledge about substances poses two significant problems. First, the way in which some courts have implemented evidentiary reform has, in all likelihood, precluded some litigants with reliable, but not ideal, scientific evidence from a jury trial. These litigants were prevented from using whatever good evidence might have been available. ${ }^{8}$ This problem may arise in part from the fact that human beings become "captured" by certain ideas; in their admissibility decisions, some courts appear to have been captured by ideas

4. See Berger, Supreme Court's Trilogy, supra note 3. Professor Berger's point about the intraand inter-circuit disagreements on general causation was sharply illustrated in a case that appeared during the final preparation of this article. The district court judge in Globetti v. Sandoz Pharmaceuticals, Corp., 111 F. Supp. 2d 1174, 1179 (N.D.Ala. 2000), rejecting the necessity for epidemiological evidence in a case involving an acute myocardial infarction allegedly caused by ingestion of Parlodel, a lactation suppression drug, disagreed sharply with other courts in evaluating the same kind of evidence because "the Daubert standard [in those cases] was applied incorrectly, creating much too high a standard of admissibility. Both of these cases seem to equate Daubert's reliability standard with scientific certainty, which is far from what the Supreme Court intended in Daubert." Id. at 1180.

5. See U.S. CONGRESS, OFFICE OF TECHNOLOGY ASSESSMENT, IDENTIFYING AND REgulating CARCINOGENS 127 (1987) [hereinafter OTA, IDENTIFYING AND REgUlATING CARCINOGENS].

6. In $1984,78 \%$ of chemicals in the U.S. with production volume greater than one million pounds per year lacked even "minimal toxicity information" in the public domain. NATIONAL RESEARCH COUNCIL, TOXICITY TESTING 84 (1984). Little changed in thirteen years; in 1997, 75\% of such substances continued to lack minimal toxicity information. See ENVIRONMENTAL DEFENSE FUND, TOXIC IGNORANCE (1997).

7. See James Huff \& David P. Rall, Relevance to Humans of Carcinogenesis Results from Laboratory Animal Toxicology Studies, in MaXCy-Rosenau Last Public Health \& PReventive MEDiCINE 433, 439 (John M. Last \& Robert B. Wallace eds., 13th ed. 1992).

8. By this we mean that some judicial opinions have mistakenly precluded litigants' use of evidence on which scientists would routinely rely for forming their conclusions. See infra notes 117-165 and accompanying text. 
about scientific evidence that are more restrictive than those utilized in the scientific community. Daubert evidentiary reform only has a chance of succeeding in the torts context if courts adopt conceptions of scientific evidence actually utilized in the scientific community. Much of this article addresses this issue.

Second, scientific ignorance about the universe of substances may be so great that current tort law rules of liability are inadequate to address properly the problems they pose. Current tort law liability rules, combined with evidentiary burdens and standards of proof, function well when both sides have plausible fact scenarios about the likelihood of what happened. When there is considerable ignorance on one side, however, as is the case in many toxic tort suits, the party with the burden of proof will lose. To address widespread ignorance about substances, courts may need to consider different legal doctrines. To protect the public better and ensure the possibility of justice between parties, courts may need to tailor new standards of liability, or shift burdens of proof once a plaintiff has presented a prima facie case to induce better testing and safety investigations by firms that create and use potentially toxic substances.

In addressing the first problem, courts need to recognize that scientific ignorance and the slow accumulation of knowledge make proving causation difficult. This creates an uncomfortable interface between science and the law. Nonetheless, the way courts choose to respond to this deficiency in scientific information can exacerbate or ameliorate the evidentiary problems. Some court responses have made things worse by imposing stringent conditions on admissible scientific evidence, ${ }^{9}$ while other courts appear sensitive to these issues. ${ }^{10}$ One consequence may be that more susceptible, but unidentified, victims of any toxic effects will be left without compensation. Even those who are not early victims or especially susceptible and who have reliable, but not ideal, evidence may be disadvantaged because of courts' admissibility decisions. As a result, some litigants with meritorious cases will not receive compensation, and the wrong signals will be sent to those who manufacture, use, and dispose of substances, thus further reducing incentives reasonably to ensure the safety of substances.

In order to maintain fidelity to both law and science without precluding justice to injured parties within current liability rules, courts must be sensitive to the tensions between science and law and to some of the subtleties of scientific reasoning. First, courts must take seriously the Daubert mandate that expert testimony must rest on a reliable scientific methodology. ${ }^{11}$ Second, they need to recognize a wider range of legitimate, respectable patterns of evidence utilized by scientists. Patterns of evidence that follow scientific methods and procedures and that are, thus, more likely than not reliable, although not mathematically infallible, should be accepted. This recommendation does not require a modifi-

\footnotetext{
9. See infra notes $117,122,130-132$ and accompanying text.

10. See infra note 118 and accompanying text.

11. See Daubert v. Merrell Dow Pharms., Inc., 509 U.S. 579 (1993).
} 
cation in the causation requirement, but it does suggest a modification in admissibility decisions by some courts.

The particular patterns on which we focus are those utilized by scientists to conclude that substances are more likely than not carcinogenic to humans. Judges need not become amateur scientists, but they do need to recognize a wider range of respectable scientific inferences, including respectable minority views, than some have to date. If courts utilize their own experts, these experts should be instructed to consider respectable minority views of evidence in the scientific community.

This first suggestion addresses some issues within the existing liability rules and the Daubert ${ }^{12}$ trilogy of cases. However, depending upon the extent of scientific ignorance and how much the above rules would increase defendants' incentives to acquire knowledge of the chemical universe, the above recommendations, even if fully implemented, may not be sufficient. In that case, courts may need to consider more far-reaching reforms. Scientific ignorance about potentially toxic substances, combined with the failure of firms to address the safety of substances, might pose such a serious problem that tort law may "not provide adequate protection against potential harm." ${ }^{13}$ One leading evidence scholar has suggested that the causation requirement should be eliminated from toxic tort causes of action in favor of a duty appropriately to test the safety of products. $^{14}$ Another alternative might be to shift the burden of proof to the defendant once the plaintiff has established a prima facie relationship between exposure and harm based on patterns of evidence similar to those that had implicated substances as likely toxic to humans. ${ }^{15}$ This and analogous suggestions merit examination in the face of scientific ignorance about the chemical universe. Reforming liability rules would relieve courts of the difficult task of struggling with arcane scientific issues and would substitute for the much more tractable task of evaluating whether firms have been responsible in testing their substances for safety. This second problem will not be a primary focus of this article.

Part II of this article briefly considers how evidentiary reform has been guided by especially good but misleading fact scenarios, and Part III reviews the extensive scientific ignorance of the universe of substances. Part IV considers some of the tensions between science and the law and judicial responses to those tensions. Part $\mathrm{V}(\mathrm{A})$ and $(\mathrm{B})$ reviews some courts' reasons for rejecting evidence and some particular mistakes of concern. Part V(C) reviews and discusses some scientifically legitimate and reliable patterns of evidence utilized by scientists to conclude that substances are more likely than not carcinogenic. Part V(D) reviews some biological principles that scientists utilize in support of

12. See Kumho Tire Co. v. Carmichael, 526 U.S. 137 (1999); General Elec. Co. v. Joiner, 522 U.S. 136 (1997); Daubert, 509 U.S. at 579.

13. Berger, supra note 2, at 2118.

14. See id. at 2117.

15. See infra note 234 and accompanying text. 
their conclusions. Finally, Part VI points to more far-reaching tort reforms that might be needed if the aforementioned suggestions are inadequate to serve the law in the face of considerable scientific ignorance about potentially toxic substances.

\section{II}

\section{EXCELLENT EVIDENCE MAKES BAD LAW}

Responding to concerns about how scientific evidence was used in two toxic tort cases ${ }^{16}$ the U.S. Supreme Court decided a trilogy of cases that instituted a number of changes in the evidentiary rules governing expert testimony. ${ }^{17}$ In brief, the trial court has a gatekeeping role in order to ensure that expert testimony is more likely than not both relevant and reliable. ${ }^{18}$ In order for proferred testimony to meet this standard, a court must ensure that it is "ground[ed] in the methods and procedures of science." determining how the gatekeeping decision is to be made as well as in making it in particular cases. ${ }^{20}$ Moreover, the Supreme Court emphasized the "liberal thrust" toward admissibility in the Federal Rules.

Some courts may have misunderstood or learned the wrong lessons from the Bendectin (and possibly the Agent Orange ${ }^{22}$ ) cases that provided the legal occasion for much of the reform. Legal scholars argue that courts have failed to recognize the unusual amount and quality of the evidence available on Bendectin, which may be one of the "best studied substances" ever, ${ }^{23}$ and may have wrongly generalized from these cases to others where the evidence is far from the best. ${ }^{24}$ Moreover, these scholars note the need for courts to recognize this improper generalization, and in the interest of evidentiary reform, have called on courts to shape the law appropriately to avoid distorting its fundamental

16. See Daubert, 509 U.S. at 579 (adjudicating the admissibility of scientific evidence of possible adverse effects from the exposure to the morning sickness drug Bendectin); Joiner, 522 U.S. at 136 (adjudicating the admissibility of scientific evidence for possible adverse effects from exposure to PCBs).

17. See Kumho, 526 U.S. at 137; Joiner, 522 U.S. at 136; Daubert, 509 U.S. at 579.

18. See Daubert, 509 U.S. at 597.

19. Id. at 588 .

20. See Kumho, 526 U.S. at 151-53.

21. See Daubert, 509 U.S. at 588. However, scholars are increasingly noting that the gatekeeping function-which invites close scrutiny of evidence-is tending to dominate the stated liberal thrust emphasis in the Federal Rules and leading to more rather than less exclusion of evidence. See Daniel J. Capra, The Daubert Puzzle, 32 GA. L. REV. 699, 754 (1998); Finley, supra note 3; Graham, supra note 3; Green, supra note 3.

22. In re Agent Orange Prod. Liab. Litig., 611 F. Supp. 1223 (E.D.N.Y. 1985).

23. Gina Kolata, Controversial Drug Makes a Comeback, N.Y. TiMES, Sept. 26, 2000, at F1 (quoting Dr. Anthony Scialli, Professor of Obstetrics and Gynecology at Georgetown University School of Medicine).

24. Michael D. Green, Bendectin And Birth Defects 312-17 (1996) [hereinafter Green, BENDECTIN AND BIRTH DEFECTS]. Excellent epidemiological studies with good exposure data and good medical records to identify any health effects of concern were available. See Michael D. Green, Legal Theory: Expert Witnesses and Sufficiency of Evidence in Toxic Substances Litigation, 86 Nw. U. L. REV. 643, 679-81 (1992) [hereinafter Green, Expert Witnesses]. 
aims. ${ }^{25}$ Further, it also appears that courts do not clearly separate the admissibility and sufficiency of evidence requirements, thus sometimes excluding experts on inappropriate grounds. ${ }^{26}$

Evidentiary reform has been a fairly blunt institutional instrument for addressing the problems of scientific evidence. With ideal evidence, ${ }^{27}$ it is appropriate to argue that human evidence, including epidemiological studies, should trump other kinds of scientific evidence available for establishing causation. ${ }^{28}$ For courts to insist on such evidence in every case, however, would be an antiquated version of "the best evidence doctrine." 29 Such excellent evidence is more likely the exception than the rule. ${ }^{30}$ For example, a review of the evidence on known and likely human carcinogens suggests that high-quality positive epidemiological studies are present for less than half of the substances. ${ }^{31}$ For all of the exposure situations without excellent human studies, drawing conclusions about the causal relation between exposure to a substance and contraction of a disease becomes a more difficult inferential exercise by an expert who must rely on all the available evidence.

III

\section{The PAUCiTy OF SCIENTIFIC EVIDENCE ABOUT THE CHEMICAL UNIVERSE}

These concerns, taken alone, should give courts and commentators pause about the evaluation of evidence in toxic tort litigation. However, there are two features about the availability of scientific evidence that further complicate this

25. See Finley, supra note 3, at 117; Green, supra note 3.

26. Courts have also abused the legal device of admissibility rulings to bring cases to a conclusion. While this clears court dockets, contributes to judicial efficiency, and perhaps manifests a desire on the part of courts to avoid being overturned on appeal, it is frequently not faithful to the status of the evidence at issue. This tends to distort the legal concepts and some of the fundamental aims of the tort law. See, e.g., Joseph Sanders, Scientific Validity, Admissibility, and Mass Torts After Daubert, 78 MINN. L. REV. 1387, 1391 (1994) (arguing that courts in Bendectin cases used inadmissibility to prevent juries from awarding verdicts to severely injured plaintiffs).

27. Ideal evidence would be multiple good epidemiological studies with large enough samples to rule out both false positive and false negative mistakes, as well as good animal studies and numerous short-term and mechanistic studies.

28. Other evidence might include human clinical evidence, laboratory studies on human tissues, or human case studies. It will probably be unusual that litigants have such excellent evidence simply because the studies are not available.

29. See Kenneth W. Cleary et Al., MCCormick on Evidence 702-03 (3d ed. 1984); Capra, supra note 21, at 716; Edward J. Immwinkelried, Should the Courts Incorporate a Best Evidence Rule into the Standard Determining the Admissibility of Scientific Testimony?: Enough is Enough Even when it is not the Best, 50 CASE W. RES. L. REV. 19, 20 (1999). But see David A. Faigman et al., Reply Essay: How Good is Good Enough?: Expert Evidence Under Daubert and Kumho, 50 CASE W. RES. L. REV. 645 (2000) (disagreeing with Immwinkelried's characterization of their views).

30. See Huff \& Rall, supra note 7, at 433; L. Tomatis et al., Avoided and Avoidable Risks of Cancer, 18 CARCINOGENESIS 97, 100 (1997) (arguing that researchers need human deaths or diseases for evidence, human exposure is variable and infrequent at relatively low levels making detection of diseases difficult, and studies are insensitive and interpreted too stringently, which may have permitted false negatives).

31. This is arrived at by considering known and probable human carcinogens as classified by the IARC and the EPA. See also Tomatis et al., supra note 30, at 100 (noting the difficulties of obtaining good human epidemiological studies of substances). 
picture. First, there is persuasive, if somewhat spotty, evidence of considerable scientific ignorance of the universe of chemical substances. ${ }^{32}$ Second, there is a growing body of literature about manufacturers' failure of care in introducing, testing, and pursuing the safety of their products. ${ }^{33}$

\section{A. Ignorance of the Universe of Chemical Substances Increases Admissibility Barriers}

First, scientists know relatively little about the universe of chemical substances. There are about 100,000 substances or their derivatives registered for use in commerce, but most have not been well assessed for health effects. ${ }^{34}$ Eight hundred to 1000 are added each year with little or no toxicity testing. ${ }^{35}$ Perhaps one-third of the substances present little or no exposure and another twenty-three percent are polymers, which pose minimal threats. ${ }^{36}$ However, in 1984, the National Academy of Sciences found that for seventy-eight percent of the 3000 top-volume chemicals in commerce, the most basic toxicity results could not be found in the public record; there has been little change in the figure as recently as $1998 .^{37}$ There may be an additional 1000 to 12,000 (beyond 3000) substances produced in quite high volumes for which extensive toxicological information would be quite important, but those results are not available. ${ }^{38}$ According to the National Academy of Sciences, an endemic problem is the "sparseness and uncertainty of the scientific knowledge of the health hazards addressed, and this problem has no ready solution." 39 Even when there is

32. See infra notes $34-49$ and accompanying text.

33. See infra notes 50-54 and accompanying text.

34. See James Huff \& David Hoel, Perspective and Overview of the Concepts and Value of Hazard Identification as the Initial Phase of Risk Assessment for Cancer and Human Health, 18 SCAND. J. WORK ENV'T HEALTH 83, 85 (1992) (estimating 50,000-100,000 chemicals in the marketplace); U.S. CONGRESS, OFFICE OF TECHNOLOGY ASSESSMENT, SCREENING AND TESTING CHEMICALS IN COMMERCE 1 (1995) [hereinafter OTA, SCREENING AND TESTING] (estimating 70,000 chemicals in commerce). If derivatives and metabolites are included, some experts suggest that the more appropriate number is 100,000. See Interview with Lauren Zeise, Chief, Reproductive and Cancer Hazard Assessment Section, California EPA (Dec. 1999).

35. See OTA, IDENTIFYING AND Regulating CARCinOGENS, supra note 5, at 127 (1987) (About one-half of the substances submitted to EPA under the premarket screening required by the Toxic Substances Control Act "reported no toxicity information and 'only seventy percent of [premanufacture notifications] have any test information about the likelihood of the substance's causing cancer, birth defects or mutations' three biological effects that were singled out for special concern in TSCA.").

36. See Huff \& Hoel, supra note 34 , at 85.

37. See NAtional Research Council, Toxicity Testing, supra note 6, at 84. This problem has become so serious that the U.S. EPA and industry entered into an agreement requiring industry to conduct the requisite studies to close the data gaps. See EPA, EDF, CMA Agree on Testing Program Targeting 2,800 Chemicals, 37 EnVTL. HeAlth LetTER (Business Publishers, Inc., Silver Spring, MD), Oct. 1998, at 193; Oil, Chemical Firms OK Environmental, Health Testing, Orange CounTy (CAL.) REG., Oct. 10, 1998, at A08.

38. See OTA, SCREENING AND Testing, supra note 34; see also Huff \& Hoel, supra note 34, at 85 (noting that about 10,000 substances pose "the most potential harm of [inducing] cancer [in] humans," and estimating that $10 \%$ to $20 \%$ might eventually be considered likely human carcinogens).

39. NATIONAL RESEARCH COUnCIL, Risk ASSESSMENT IN THE FEDERAL GOVERnMENT: MANAGING THE PROCESS 6 (1984). 
an understanding of some features of toxicants, there may be woeful ignorance about many other toxic properties. ${ }^{40}$

Second, federal agencies that are charged with protecting the public health and are aware of the toxic properties of substances have been slow to conduct health assessments needed for regulations. The Office of Technology Assessment found in 1987 that of the known carcinogens, federal regulatory agencies had addressed only one-half to one-third within their jurisdiction. ${ }^{41}$ Of the universe of substances, there are only about 100 for which there is sufficient evidence with which to begin a health assessment of their risks as air toxicants. ${ }^{42}$ If agencies charged with assessing substances have not assimilated such information, it is unlikely that others have. ${ }^{43}$

Third, according to standard toxicology references, even when substances are well known and have been studied extensively, such as aspirin, there can remain substantial gaps in scientific understanding of their toxic effects. ${ }^{44}$

These knowledge gaps can be even worse for toxicants with long latency periods, such as those that cause cancer or reproductive harms, two effects of particular concern to the public. The latency period for cancers typically varies from a few to more than forty years. ${ }^{45}$ Thus, identifying the causal connection between an exposure and development of the disease can be quite difficult. Some adverse reproductive effects, such as shortened limbs, are manifested at birth and are immediately evident on inspection, while others, including multigenerational effects, may take much longer to appear or may not be easily detectable. When the adverse effects are difficult to detect, such as a reduction in intelligence, as opposed to a reduction in limb length, there will be additional problems.

Fourth, there will likely be even greater knowledge gaps for other kinds of substances, such as some fuels and solvents. These substances are likely to hold

40. See id.

41. See OTA, IDENTIFying AND REgulating CARCinOgens, supra note 5, at 9-22.

42. See George Alexeef, Deputy Director, Office of Environmental Health Hazard Assessment, California Environmental Protection Agency, Seminar at University of California Riverside (Nov. 15, 1999).

43. See OTA, IDENTIFYING AND REgUlATING CARCINOGENS, supra note 5, at 9-22; see also AFL-CIO v. Occupational Safety and Health Admin., 965 F.2d 962, 987 (11th Cir. 1992) (recognizing the need for OSHA to regulate a large number of substances quickly to make major strides in protecting worker health and safety, but invalidating its attempt to do so).

44. A typical text notes that aspirin has numerous therapeutic effects. At high doses it can also cause a number of adverse or toxic effects. At higher doses, there is "direct stimulation of the respiratory center." See Kenneth S. Santone \& Garth Powis, Mechanism of and Tests for Injuries, in HANDBOOK OF PESTICIDE TOXICOLOGY 169 (W.J. Hayes, Jr. \& E.R. Laws, Jr. eds., 1991). There are also central nervous system effects in the form of "tinnitus and hearing loss and central respiratory paralysis. ... [V]ery high doses ... [also cause] . . circulatory collapse due to vasomotor depression." Id. These are just a few of the adverse biological effects of aspirin. See id. We know the mechanism of action of some of these effects, but little about the mechanism of others. See id.

45. Malcolm A. Smith et al., Therapy-Related Acute Myeloid Leukemia Following Treatment with Epipodophyllotoxins: Estimating the Risks, 23 MEDICAL \& PODIATRIC ONCOLOGY 86, 87 (1994) (latency period as short as 10 months, with a median of 30 months, from chemotherapy treatments); U.S. Dept. of Health and Human Services, Toxicological Profile for Asbestos 6, 28 (1995) (latency period from exposure to asbestos is 10 to 40 years). 
so little fundamental scientific interest for researchers or funding agencies interested in basic research that they will be poorly studied. Yet, as some recent cases indicate, they may come to the attention of the tort law because they are involved in accidental exposures. ${ }^{46}$

Fifth, for substances that are the object of study, it takes time-as well as substantial monetary and human resources-to do the needed toxicity research on particular substances to overcome the ignorance. ${ }^{47}$ Simply to accumulate the needed scientific evidence can be quite time consuming. For example, utilizing various kinds of non-human evidence and conducting expedited studies generally takes six years or more to generate a standard battery of test results with which to assess the basic toxicity of a substance. ${ }^{48}$ Providing human evidence would further delay evaluation.

Finally, even after some in the scientific community are persuaded of the toxicity or lack of toxicity of a particular substance, it takes longer still to establish a scientific consensus on the point. If courts require a consensus on the toxic properties of a substance, as some commentators have suggested (but which Daubert does not), this will preclude justice for many meritorious claimants and greatly delay it for others. ${ }^{49}$

\section{B. Corporate Failure to Determine Products Safety}

These problems might arise from the regular, flawed, but nonculpable, operations of a laissez-faire economic system, which have resulted in the production of thousands of substances without much oversight or testing, and the slow process of knowledge accumulation in science. This alone would raise questions about whether the current legal structure is adequate to review the toxicity of the myriad substances created by companies, to ensure compensation to wrongly injured victims, and to prevent others from being harmed.

However, some research suggests that chemical ignorance may arise in part from the deliberate actions of some who manufacture and use potentially toxic substances. Professor Berger summarizes this by noting that, often,

the corporation in question did not test its product adequately initially, failed to impart information when potential problems emerged, and did not undertake further research in response to adverse information. It appears that the corporations took virtually no steps to determine or minimize the possibility of harm until their hands were forced, usually by litigation. Only after extensive and expensive discovery have

46. See Moore v. Ashland Chem. Inc., 151 F.3d 269 (5th Cir. 1998) (adjudicating the admissibility of scientific evidence concerning possible adverse effects from exposure to solvents); Cavallo v. Star Enter., 892 F. Supp. 756 (E.D. Va. 1995) (adjudicating the admissibility of scientific evidence concerning adverse effects from jet fuel exposure).

47. See Huff \& Rall, supra note 7, at 439.

48. See Robert C. James, General Principles of Toxicology, in Industrial ToXIOLOGY 7, 20 (P.L. Williams \& J.L. Burson eds., 1985).

49. See Kenneth R. Foster \& Peter W. Huber, Judging SCIEnce: Scientific KNowledge AND THE FEDERAL COURTS 184-86, 243-45, 247 (1997). 
documents and witnesses come to light that showed the corporations' awareness of potential problems. ${ }^{50}$

Similar conclusions are suggested frequently in newspaper reports, such as the stories concerning the Bridgestone/Firestone tire failures. ${ }^{51}$ Such conduct is not restricted to the private sector, as governmental agencies may not always be forthcoming either. ${ }^{52}$ Moreover, although standardized test protocols are designed to minimize this, it is comparatively easy to design studies that are unlikely to detect harms or risks of concern. Furthermore, there are temptations or pressures to refrain from testing altogether. Sometimes laboratories used by industries have been subject to criminal liability for their testing failures. ${ }^{53}$ Some firms or industries have aimed to subvert the results of independent scientific studies or manipulate data and studies for their own benefit. ${ }^{54}$ Such actions further delay or eliminate altogether the possibility of a just resolution of meritorious claims and undermine any deterrent effect of tort claims.

\section{Scientific Ignorance and Tort Law Burdens of Proof}

Even though the Supreme Court's decisions on evidentiary reform have emphasized the need for expert testimony to rest on scientific knowledge, it is scientific ignorance that looms so large in the world of chemical substances and

50. Berger, Eliminating General Causation, supra note 2, at 77-84 (citing studies of Agent Orange, asbestos, Bendectin, breast implants, the Dalkon Shield, thalidomide, tobacco, MER/29 (a cholesterolreducing drug that caused cataracts), alachlor, atrazine, formaldehyde, and perchloroethylene).

For a discussion in the toxicological literature of some of these and other issues, see Barry I. Castleman, Regulations Affecting Use of Carcinogens, in CANCER CAUSING CHEMICALS 78 (Newton I. Sax ed., 1981); David E. Lilienfeld, The Silence: The Asbestos Industry and Early Occupational Cancer Research: A Case Study, 81 AM. J. PuB. HeAlth 791, 791-98 (1991); David Michaels, Waiting For The Body Count: Corporate Decision Making and Bladder Cancer in the U.S. Dye Industry, 2 MED. ANTHRO. Q. 215, $217-27$ (1988); cf. Lori Ann Thrupp, Sterilization of Workers From Pesiticide Exposure: The Causes and Consequences of DBCP-Induced Damage in Costa Rica and Beyond, 21 INT'L J. HEALTH SERVICES 731 (1991).

In some instances, even responsible firms may also fall prey to ambiguity and difficulty in interpreting data and scientific studies.

51. See Ricardo Alonso-Zaldivar \& Davan Mahara, Tests Show Firestone "Had to Know," Probers Say; Safety: Congress Cites New Evidence Against Tire Maker as Sentiment Swings in Favor of Criminal Penalties in Such Cases, L.A. TIMES, Sept. 21, 2000, at C1; Richard A. Oppel, Jr., Environmental Tests "Falsified," U.S. Says, N.Y. TIMES, Sept. 22, 2000, at A14; Melody Petersen, Settlement Is Approved in Diet Drug Case, N.Y. TIMES, Aug. 29, 2000, at C2; David Willman, The Rise and Fall of the Killer Drug Rezulin; People Were Dying as Specialists Waged War Against Their FDA Superiors, L.A. TIMES, June 4, 2000, at A1; David Willman, Risk Was Known as FDA Ok'd Fatal Drug, L.A. TiMES, Mar. 11, 2001, at A1.

52. See, e.g., GAYle Greene, The Woman Who Knew Too Much (1999) (describing governmental attempts in the United States and Great Britain to preclude researchers from data and vigorously to fight their findings concerning exposures to nuclear radiation); Matthew L. Wald, U.S. Acknowledges Radiation Killed Weapons Workers, N.Y. TimES, Jan. 29, 2000, at A1.

53. See Samuel S. Epstein, Corporate Crime: Why We Cannot Trust Industry-Derived Safety Studies, 20 INT'L J. HEALTH SERVICES 433, 454-55 (1990).

54. See Elisa K. Ong \& Stanton A. Glantz, Tobacco Industry Efforts Subverting International Agency for Research on Cancer's Second-hand Smoke Study, 355 LANCET 1253, 1254, 1256 (2000) (noting that an independent research group such as IARC spent \$1.5-\$3 million to study second-hand smoke, while one tobacco company planned to spend up to $\$ 6$ million to undermine the credibility of IARC's work); Epstein, supra note 53, at 454-55; Oppel, supra note 51. 
in many toxic tort cases. When there is evidence that a plaintiff has been exposed to a defendant's substance, plaintiff must show that defendant's substance more likely than not causes the kind of injury from which plaintiff suffered (general causation) and that it more likely than not did cause plaintiff's injuries (specific causation).

Functionally, these burdens of proof can be made more difficult to carry due to a lack of scientific knowledge, the behavior of some corporations, and the ways courts have understood and implemented evidentiary reform. Whether or not courts should admit scientific testimony in many particular cases may be a close call because the available evidence on which an expert could rely for testimony often will not be ideal. Thus, in deciding particular cases, and in framing rules to guide the admission of expert testimony, courts must face up to the reality of scientific ignorance about chemical substances, their properties, and the erratic and accidental exposure conditions that may lead to injury to permit litigants to use whatever reliable evidence is available. Legally, the courts also need to recall that tort law protects even the most sensitive and vulnerable persons by means of the "eggshell skull" principle..$^{55}$

Lack of scientific knowledge, however, invites a defendant whose substance is challenged as harmful to utilize ignorance as a means to avoid liability. Even if a defendant has done some research on a product and its side effects, or has received health reports concerning adverse effects, it may still be tempted to utilize ignorance about a substance's properties in its defense. ${ }^{56}$ It might prevail on this basis alone because the claim that toxic effects in humans have not been proven is relatively easy to defend, as the tobacco industry showed over many years. Moreover, even if the scientific case has considerable merit, it will be comparatively easy to find scientists who will argue that too little is known about the toxicity of a substance as long as there is not a broad scientific consensus on the issue. Courts should be sensitive to this dynamic.

Against the above background, stringent evidentiary requirements impose a particular hardship on toxic tort plaintiffs who must establish causation scientifically. In torts litigation, the higher the standard that must be met before a finding is justified, scientific evidence is admitted, or a burden of production is satisfied, the easier an adversary's task becomes, because the opposing party may be "more inclined to rest on the noncredibility of the proponent's proofs, and less inclined to produce affirmative evidence." ${ }^{57}$ Such standards will not minimize the weighted number of mistakes between plaintiffs and defendants, ${ }^{58}$

55. See W. Page Keeton et Al., Prosser and Keeton on The Law Of Torts $§ 43$, at 291-92 (5th ed. 1984).

56. This applies to products, but often the object of suits is not so much products as pollutants from processes or contaminants in products or the use of products manufactured by others.

57. Vern R. Walker, Preponderance, Probability and Warranted Fact Finding, 62 BroOK. L.R. 1075, 1115 (1996).

58. See Green, Expert Witnesses, supra note 24, at 643, 687. 
and will reduce incentives for opponents to produce their own affirmative evidence, thereby frustrating two aims of tort law. ${ }^{59}$

\section{Injuries Long Precede the Scientific Understanding of the Causes of Injury}

Injury from a substance might easily precede scientific understanding and documentation of that fact by years, if not decades. The point is not merely that tort law compensation is retrospective, but also that in many cases, it can take years to have clues that substances cause harm, even longer to document the cause of damage, and longer yet to develop a consensus on the issue. Whether scientists can ever have a full understanding of the toxicity of many substances in humans is an even more contested issue.

Consider benzene, an important industrial product and by now a wellknown human carcinogen. Benzene was implicated in the 1890s in causing various blood diseases. ${ }^{60}$ In the $1920 \mathrm{~s}$, it was reported to cause leukemia. ${ }^{61}$ However, scientific documentation of, and substantial agreement on, benzene's leukemogenic properties did not come for another sixty years, when the World Health Organization's International Agency for Research on Cancer ("IARC") addressed it. In 1974, the IARC noted that it could indicate only that a relationship between benzene exposure and the development of leukemia was "suggested" by case reports and one case-control study. ${ }^{62}$ By 1982, the same organization had found that there was sufficient evidence that benzene was carcinogenic to $\operatorname{man},{ }^{63}$ and in 1987 , it confirmed that benzene "is carcinogenic to humans." ${ }^{\circ 4}$ Surely people were contracting leukemia long before 1982 or 1987, and probably at higher rates than were seen in the 1970s and 1980s. However, until the last two decades, there would have been little scientific consensus about that conclusion. Thus, there would have been no compensation for anyone who contracted leukemia from benzene exposure until there was "appropriate" documentation of the injuries in question. ${ }^{65}$

59. See Walker, supra note 57, at 1115.

60. See Larry S. Andrews \& Robert Snyder, Toxic Effects of Solvents and Vapors, in CASARETT AND Doull's TOXICOLOGY 681, 686 (Mary O. Amdur et al. eds., 4th ed. 1991); H.G.S. van Raalte \& P. Grasso, Hematological, Myelotoxic, Clastogenic, Carcinogenic, and Leukemogenic Effects of Benzene, 2 Regulatory TOxicol. Pharmacol. 153, 153-76 (1982); Robert Snyder, The Benzene Problem in Historical Perspective, 4 FUND APPL. TOXICOL. 692-99 (1984).

61. See Snyder, supra note 60, at 692-99.

62. IARC website (visited Apr. 4, 2001) <http://193.51.164.11/htdocs/monographs/vol07/Benzene .html>.

63. See IARC, World Health Organization (WHO), Benzene, Summary of Data Reported and Evaluation (1982) (last modified Apr. 9, 1998), available at <http://193.51.164.11/htdocs /monographs/Vol29/Benzene.html>.

64. IARC, WHO, Benzene: Supplement 7 (1987) (last modified Feb. 6, 1998), available at $<$ http://193.51.164.11/htdocs/monographs/Suppl7/Benzene.html>.

65. For example, Marvin Sakol, a hematologist, testified during the OSHA hearings on benzene that for one leukemia patient with an occupational history of benzene exposure the discharge diagnosis was changed from leukemia to aplastic anemia so his "widow would receive $\$ 10,000$ in industrial compensation." Occupational Exposure to Benzene, 50 Fed. Reg. 50512 (proposed Dec. 10, 1985). 
Benzene is not an isolated case; similar problems have attended the scientific discovery of the adverse health effects of arsenic, dioxin, asbestos, and other substances. The future may not be quite as bad as the past in this regard because scientists are more aware of possible toxic effects, and better scientific procedures are available than in the past. Although there is little systematic evidence on this point, benzene may be more representative than a substance such as Bendectin, for which there was a relatively quick scientific evaluation. ${ }^{66}$ Thus, slow knowledge accumulation poses serious problems. The more stringent courts are in screening scientific testimony, the more this will exacerbate the problems. Statutes of limitation only add to the problem. ${ }^{67}$

\section{IV}

\section{IMPLEMENTING EVIDENTIARY REFORM IN THE FACE OF LIMITED SCIENTIFIC KNOWLEDGE}

Short of major modifications in tort law liability and consistent with the requirements of Daubert, courts can take some steps to address the problems described above. To do this, however, they must have a better generic understanding of science, some of the tensions between science and law, and some of the main patterns of evidence that respectable scientists and scientific bodies utilize to conclude that substances are harmful to humans.

To the extent that for some substances there is a substantial delay between the initial injuries and scientific documentation of the causal contribution of harm, evidentiary admissibility principles must be crafted to permit expert testimony as early as practicable in the discovery of causes of particular diseases. Otherwise, citizens may be injured but have no means of redress against those whose substances have caused harm, and deterrence signals will not be sent to manufacturers.

As a result of the Daubert trilogy ${ }^{68}$ federal district court judges must address the above issues, and they have considerable latitude in doing so. ${ }^{69}$ These judges can be reversed only if their decisions are "manifestly erroneous." "While this is not an impossible review hurdle for appellants to overcome, it is an extraordinarily difficult one. ${ }^{71}$

66. See William J. Nicholson, IARC Evaluations in the Light of Limitations of Human Epidemiologic Data, 534 ANN. NY ACAD. SCI. 44, 44-45 (1988) (showing that for about 18 substances, exposure conditions or processes that are carcinogenic and that have quite high relative risks, there has been evidence of their human carcinogenicity for many decades, but action on them occurred only within the past 10 to 20 years).

67. See Green, Bendectin and Birth Defects, supra note 24, at 192, 208.

68. See Kumho Tire Co. v. Carmichael, 526 U.S. 137 (1999); General Elec. Co. v. Joiner, 522 U.S. 136 (1997); Daubert v. Merrell Dow Pharms., Inc., 509 U.S. 579 (1993).

69. See Kumho Tire, 526 U.S. at 139.

70. Joiner, 522 U.S at 142.

71. See Cooter \& Gell v. Hartmarx Corp., 496 U.S. 384, 400-01 (1989) (quoting Anderson v. Bessemer City, 470 U.S. 564, 573-74 (1985)):

[I]f the district court's account of the evidence is plausible in light of the record viewed in its entirety, the court of appeals may not reverse it even though convinced that had 
Such gatekeeping rules and the issues at stake, however, increase courts' responsibilities to perform their tasks well and to ensure that the goals of tort law within existing liability rules and scientific evidence are satisfied. ${ }^{72}$ To fulfill this responsibility, courts need a better understanding of some of the institutional tensions between science and the law.

\section{A. Generic Tensions Between Science and the Law}

1. Tension in Goals. The principle aim of science is epistemic: Scientists aim to describe and understand accurately the phenomena they study. ${ }^{73}$ By contrast, tort law aims at a just resolution of disputes between parties. Other normative goals, such as, inter alia, efficiency, administrative cost, wealth distribution, and morality also shape the law. This has led one commentator to note that the law is "normative to the core," "74 which is something unlikely to be said of science, despite the presence of some normative elements. Epistemic principles in the law should be consistent with and serve these social goals.

There is a collaborative aspect to science that aims ultimately at developing a consensus about the subject of study. This ultimate goal can be misleading if it is overemphasized, however. There is considerable disagreement between respectable experts during the process of reaching consensus, leading some to suggest that "science is above all an adversarial process." ognize this fact of disagreement in science and permit differing respectable views to be admitted. $^{76}$ The law at its core is quite adversarial, which invites different interpretations of law, facts, and disputes for courts to adjudicate to arrive at a just resolution of the issues. To accommodate these features, the law should provide a place for disagreement between respectable scientific views.

Science is relatively open-ended; conclusions, even comparatively settled ones, are open to revision upon the presentation of new data, theories, or discoveries. By contrast, the law seeks to resolve disputes in a timely and conclusive manner. The open-endedness of science, and the practices that accompany

it been sitting as the trier of fact, it would have weighed the evidence differently. Where there are two permissible views of the evidence, the fact-finder's choice between them cannot be clearly erroneous.

72. We raise later the question of whether current liability rules are adequate.

73. In toxicology, the issue is more complicated. Some toxicologists aim to recognize, identify, and quantify the hazards from toxic substances to humans and the environment, some to create new drugs or pesticides, while some engage in more basic research in order to understand the mechanism(s) of action of substances. See Michael A. Gallo \& John Doull, History and Scope of Toxicology, in CASARETT AND DOULL's TOXICOLOGY, supra note 60, at 3.

74. Peter H. Schuck, Multi-Culturalism Redux: Science, Law, and Politics, 11 YALE L. \& POL'Y REV. 1, 24 (1993).

75. David Goodstein, How Science Works, in REFERENCE MANUAL ON SCIENTIFIC EvidenCE, supra note 3, at 9, 74 (Fed. Judicial Ctr. ed., 2d ed. 2000). Douglas Crawford-Brown illustrates how easy it is for scientists to disagree even if they concur in the basic evidence. See Scientific Models of Human Health Risk Analysis in Legal and Policy Decisions, 64 LAW \& CONTEMP. PROBS. 63 (Autumn 2001).

76. Sometimes the consensus view so dominates scientific inquiry that respectable views can be wrongly excluded from consideration. For one example, see GREENE, supra note 52. 
it, can affect the communication between science and the law. Scientists, aware of the tentative nature of scientific conclusions, may be professionally reluctant to assert findings with confidence and thus may hedge even well-supported claims. $^{77}$ Judges need to recognize this because such hesitancy can mislead courts and disadvantage meritorious litigants with respectable evidence who carry the burden of proof to establish a claim.

Most important for what follows, science for the most part does not attend to the distributive consequences of its results or mistakes that can result from institutional outcomes. ${ }^{78}$ By contrast, in the law, the justice of results, any mistakes that might result from decisions, and the distributive effects of legal rules and decisions are of preeminent importance. In particular, in tort law, both the compensatory and distributive effects of decisions and rules matter. If scientific approaches to distributions of mistakes or conceptions of accuracy dominate in the law, they risk distorting the law's goals. Thus, the various techniques, inference practices, and cautious data interpretation that scientists have developed must be utilized sensitively in the law, or they will pose problems. Aspects of this problem are discussed below.

2. Tensions Between Scientific and Legal Epistemic Practices. In tort law, evidentiary procedures with which adversaries must comply might be considered part of the requirements that collectively aim at not exceeding a tolerable balance of mistakes - of legal false positives/false negatives-between parties and at achieving other nonepistemic institutional goals, such as serving justice, and providing fair procedures to litigants. While tort law does not endorse casual rejection of the status quo, standards of proof embedded in its burdens of production and persuasion do not appear as demanding as scientific standards of proof, and there is a different emphasis on mistakes that might result. ${ }^{79}$ In short, tort law is "indifferent as between a plaintiff's erroneous recovery [a legal false positive] and a defendant's erroneous non-liability [a legal false negative]," thus reflecting important non-epistemic values, such as the risk of injustice between parties. ${ }^{80}$

77. See infra notes 78-82 and accompanying text (discussing the concept of scientific hedging).

78. That is, it is not part of basic scientific research to address how scientific mistakes might affect other institutions, nor is there concern within science with how false positives and false negatives might affect the institution of science (apart from avoiding false positives). This is very different from the law, which has a self-conscious concern with such matters.

79. See In re Winship, 397 U.S. 358, 371-72 (1970); Speiser v. Randall, 357 U.S. 513, 525-26 (1958); see also Green, Expert Witnesses, supra note 24, at 697.

80. Santosky v. Kramer, 455 U.S. 745, 755 (1982) (adopting the standard set forth in Addington v. Texas, 441 U.S. 418, 423 (1979), that "in any given proceeding, the . . standard of proof . . reflects not only the weight of the private and the public interests affected, but also a societal judgment about how the risk of error should be distributed between the litigants"); Green, Expert Witnesses, supra note 24, at 687 .

Legal and factual false positives (or false negatives) are not identical, of course. However, when there are a few pieces of evidence that are critical to a litigant's case, a factual error will more likely translate into a legal mistake. 
Science has different commitments that can have undesirable consequences for the law. The goals of understanding phenomena and adding carefully to the knowledge status quo have led the scientific community to adopt certain selective evidentiary procedures in order to remove ignorance about substances.

Scientific bodies and most scientists are typically quite demanding in preventing factual false positives, that is, that their procedures show that a substance has a toxic property when in fact it does not. ${ }^{81}$ One rationale for this, reflecting research concerns, is that scientists want to be sure that scientific contributions added to the edifice of science are well-supported. They also seek to ensure that the research community is not chasing chimera. Thus, an unusual caution toward certain kinds of inferences permeates scientific research. ${ }^{82}$ This is accompanied by skepticism toward such inferences as well as a demand for considerable caution before the inferences are endorsed. Such caution protects and helps regulate the field and its development. It also serves self-regulation by discouraging individuals from overly enthusiastically advocating their own ideas and wasting their own and others' research efforts.

More positively, scientists develop virtues, skills, and techniques that lead to a certain distribution of mistakes, help resist casually overturning the hardearned epistemic status quo, facilitate adding carefully to the knowledge status quo, and improve their understanding of the phenomena. Such concerns lead to the erection of substantial barriers to protect the research status quo, which in the case of most substances is simple lack of information about their properties. $^{83}$

There can also be scientific mistakes in the other direction by chance alone, such as factual false negatives, in which procedures fail to detect a toxic property of a substance when in fact it exists. This seems less important to the scientific community than preventing false positives. A rationale for having less stringency in preventing false negatives may be that over time true positive results will be revealed. ${ }^{84}$ While this may be appropriate for scientific research, it poses problems for the law, because it leaves potential victims at risk and actual victims uncompensated.

Because they are rarely articulated, finding systematic statements about the stringency of scientific inferential views can be difficult. However, the following considerations provide some evidence for this claim. First, scientists guard against random errors producing false positive results by demanding that support for their conclusions must be statistically significant. ${ }^{85}$ Unthinking commitment to this goal can increase false negatives. ${ }^{86}$ Moreover, thoughtful com-

81. See CARl F. CRAnOr, Regulating Toxic Substances: A Philosophy of Science And THE LAW 32-34 (1993); infra notes at 85-95 and accompanying text.

82. See infra notes $85-95$ and accompanying text.

83. See infra notes $85-103$ and accompanying text.

84. See CRANOR, supra note 81.

85. That is, there must be less than five percent (or sometimes less than one percent) odds by chance alone (as a result of sampling or experimental error) of a factual false positive.

86. See CRANOR, supra note 81 , at 31-39. 
mentators are increasingly concerned about rigidly using statistical significance as a decision rule. ${ }^{87}$

Second, epistemic conservatism concerning the knowledge status quo is not confined to statistical tests. One well-known toxicologist argues that before scientifically labeling a substance a human carcinogen, one needs multiple epidemiological studies, multiple animal studies subjected to strict experimental conditions (so there is an animal model for the toxic effect), and multiple shortterm studies that might indicate the activity of the substance-the mechanism by which it works - and other detailed features of the substance. ${ }^{88}$ In the absence of such complete information, he would be reluctant to judge a substance to be a human carcinogen. The problem with this view is that the scientific community has such substantial information for only a very few substances, ${ }^{89}$ and it would be extremely expensive and take one or more decades to accumulate the recommended data about substances such as carcinogens. ${ }^{90}$ His requirements might necessitate even more evidence than was available in the Bendectin cases, which dealt with an alleged reproductive toxicant. ${ }^{91}$

Another scientist, perhaps following the discredited philosophy of science of Karl Popper, ${ }^{92}$ has articulated analogous views about the importance of ruling out alternative hypotheses before drawing a conclusion. Scientists, he claims, seek to establish causal connections with "proof . . . usually accepted in science" or possibly proof "beyond a reasonable doubt" because alternative explanations will slay "a beautiful [but mistaken] hypothesis." "93 The "beyond a reasonable doubt" language is revealing because it is one of the most demanding in the law. Using this standard in toxicology would require that if there were any reason-

87. See id. at 32; Gerd Gigerenzer, The Superego, the Ego and the Id in Statistical Reasoning, in A HANDBOOK FOR DATA ANALYSIS IN THE BEHAVIORAL SCIENCES: METHODOLOGICAL ISSUES 311 (Gideon Keren \& Charles Lewis eds., 1993); Gerd Gigerenzer, From Tools to Theories: a Heuristic of Discovery in Cognitive Psychology, 98 PsYCH. REV. 254 (1991); Deidre N. McCloskey \& Stephen T. Ziliak, The Standard Error of Regressions, 34 J. ECON. LIT. 97 (1996); Peter Sedlmeier \& Gerd Gigerenzer, Do Studies of Statistical Power have an Effect on the Power of Studies, 105 PSYCH. BuLL. 309, 315 (1989) (noting the need for sensitivity in applying yes-no statistical tools).

88. See Arthur Furst, Yes, But is it a Human Carcinogen?, 9 J. AM. C. Toxicology 1 (1990).

89. Out of 736 agents that the World Health Organization had evaluated for carcinogenicity as of 1998, 74 substances were known human carcinogens (these might satisfy Furst's criteria), 56 were "probably" human carcinogens (which would not satisfy his criteria), and 225 were classified as "possibly" human carcinogens. See IARC MONOGRAPHS, Vols. 1-71 (1972-98), summarized at the IARC website (last modified Mar. 5, 1998) <http://193.51.164.11/monoeval/grlist.html>.

90. See James, supra note 48.

91. See Green, Bendectin and Birth Defects, supra note 24, at 314-15.

92. See Goodstein, supra note 75 , at 71 (noting, along with many others, that the testability of a scientific claim is not adequate to demarcate scientific from non-scientific claims or methods). Karl Popper's views have long been rejected by philosophers of science as a criterion demarcating science from non-science. See generally Susan Haack, EVIDENCE AND INQUIRY: TOWARDS RECONSTRUCTION IN EPISTEMOLOGY (1993).

93. H.J. Eysenck, Were We Really Wrong?, 133 AM. J. Pub. HeAlth 429-32 (1991). But cf. Sander Greenland, Invited Commentary: Science versus Public Health Actions: Those Who Were Wrong are Still Wrong, 133 AM. J. PUB. HEALTH 435-36 (1991) (arguing that since it is always possible to claim there are unknown co-founders, views of critics such as Eysenck would make public health actions very difficult). 
able doubts about the toxicity or other properties of a substance, one should not conclude that a substance has them. This is, we suggest, much too demanding for tort law's admissibility standards, or its ultimate standard of proof.

Judges will be exposed to such stringent views, and if courts embrace them as minimum standards for admissibility, this would preclude many experts from testifying in toxic tort cases, and would impose considerable hardships on litigants, especially injured parties. As will be shown, there is respectable and reliable scientific evidence implicating substances as toxic to humans that falls well short of such demanding standards ${ }^{94}$ moreover, not all scientists are so extreme in their reluctance to draw inferences.

Third, James Huff and David Rall, two leading environmental health experts, have suggested a further explanation why toxicologists in particular may be reluctant to conclude that substances are harmful to humans. Scientists who normally propose and test hypotheses on animals and other non-human systems may be reluctant to predict effects on humans from exposures to substances. However, because of legitimate moral constraints on testing humans, scientists are for the most part denied the opportunity to test predictions of effects on humans. Thus, the

laboratory scientist, accustomed to being able to close the circle from hypothesis, to
test, to acceptance or rejection, to new hypothesis generation, is uncomfortable when
lawyers, economists, journalists, and politicians take the hypothesis and use it in a sys-
tem in which the circle cannot be closed and in which the answer often cannot be
known with certainty. In fact in most basic research areas the "circle" is rarely closed;
the usual course of events leads to other questions that need answering.

To the extent that scientists implicitly aim at certainty, as Huff and Rall suggest, this poses two problems: (1) It will be difficult, if not impossible, to support many inferences about adverse human effects with certainty; and (2) reputable scientists may believe it is necessary to hedge their claims in scientific papers because conclusions cannot be established with certainty. Hedging creates a further source of confusion between science and the law that makes judges' tasks even more difficult. Hedging, a phenomenon that has been wellstudied by applied linguists and rhetoricians, "express[es] tentativeness and possibility in communication." 96 This is such an endemic rhetorical practice of scientists that unless judges understand it, it is likely to mislead them.

There are several reasons for hedging in scientific articles. To some extent, it serves epistemic purposes; it may indicate: (1) a lack of complete commitment to the truth value of an accompanying proposition, or (2) a desire not to express that commitment categorically. ${ }^{97}$ Scientists also typically understand the limitations of their studies and the open-endedness of science. ${ }^{98}$ Some hedging may indicate lack of appropriate certainty in a conclusion. Even if scientists

94. See infra notes 166-197 and accompanying text (Section VC).

95. Huff \& Rall, supra note 7, at 433 (emphasis added).

96. Ken Hyland, HedGing IN SCIENTIFIC RESEARCH ARTICLES 1 (1997).

97. Id. at 64-74.

98. See id. 
hedge because they are not certain of their conclusions, they may still have quite reliable evidence. ${ }^{99}$

However, there are other reasons for hedging that do not represent a lack of confidence in a conclusion. Hedging may help persuade others by presenting one's own views cautiously and with humility, or express research results in an understated way to a community that can readily comprehend the research. It may help to define one's own relation to the rest of the scientific community, to facilitate acceptance and publication of the research, to express a kind of politeness toward peer researchers (and avoid threatening previous achievements or limiting future research), to avoid violating community norms that might result in sanctions toward oneself, or to shield the author from challenges by others. ${ }^{100}$

Laypersons, including most judges, are likely to understand hedged comments as a lack of epistemic confidence in research conclusions. However, this would be a mistake. There clearly are reasons for hedging that have little or nothing to do with weak support for one's conclusions. This was notably illustrated in James Watson and Francis Crick's justly famous paper on the structure of DNA. ${ }^{101}$ Thus, even though a scientific paper does not claim certainty for a conclusion that a toxic substance causes human harm, the author may well have believed that harm was probable (or even fairly certain). The degree of certainty with which scientists believe conclusions is not necessarily accurately expressed in the language of their published papers. Hedging language becomes a term of art or has technical meanings that diverge from ordinary uses. Hence, a scientist who might verbally express greater confidence in her research than is indicated in her published papers would not be trying to mislead others.

Moreover, other scientists reviewing the same data might come to stronger conclusions. This would not necessarily be a mistake. In fact, according to some scientists, as well as linguists who have studied this issue, tentative claims are proposed to the community of scientists for their adoption. ${ }^{102}$ As others become persuaded of the claims, even though no new evidence has emerged to support them, scientists' confidence in the results increases. This is part of consensus formation.

99. See Michael D. Green et al., Reference Guide on Epidemiology, in REFERENCE MANUAL ON SCIENTIFIC EVIDENCE, supra note 3, at 375 (quoting Berry v. CSX Transp., Inc., 709 So. 2d 552, 568 n.12 (Fla. Dist. Ct. App. 1998), stating that

almost all genres of research articles in the medical and behavioral sciences conclude their discussion with qualifying statements such as "there is still much to be learned." This is not, as might be assumed, an expression of ignorance, but rather an expression that all scientific fields are open-ended and can progress from their present state.

100. See HYLAND, supra note 96.

101. See id. at 65 ([While telling] "anyone who would listen that they had discovered the secret of life," their published conclusion was "[w]e wish to suggest a structure for. . . DNA ... [which] has novel features which are of considerable biological interest.").

102. See id. at 64-74. 
The collective effects of the most stringent scientific burdens of proof-as well as the standards of proof ${ }^{103}$ against which they must be satisfied-are reinforced by the skepticism described above because they play an important and legitimate role in the "institution" or "practice" of science. However, the combined effect of scientific ignorance, cautious inference drawing, hedging in scientific articles, and slow knowledge accumulation presents difficulties for tort law. To the extent that there is a substantial delay between identification of the initial injuries and scientific documentation of the causal contribution of harm, judicial principles must be crafted to permit expert testimony as early as practicable in the history of the discovery of the toxic properties of those substances. Otherwise, actual victims of toxic exposures will have no redress against those responsible, and the deterrence function of tort law will be reduced. In addition, judges must be sensitive to scientific hedging and other scientific practices that can lead to misunderstandings between the scientific and legal communities.

\section{B. Judicial Responses to the Science/Law Interaction}

Some courts have exacerbated the above problems with the standards they have utilized to review reasonable scientific evidence for admissibility. Some have had mistaken conceptions of scientific evidence contrary to those on which scientists themselves rely. ${ }^{104}$ This will undermine the aims of the Daubert Court to provide better support for legal decisions that utilize scientific evidence. ${ }^{105}$ It also leaves judges at the mercy of litigants in presenting the issues.

One generic error would be an explanatory mistake, which is a judicially imposed restriction on the content of evidence that is incompatible with scientific evidence evaluation or judicially imposed restrictions on the form of reasoning that experts must follow that are contrary to the good evaluation of evidence. $^{106}$ Courts have not always recognized respectable patterns of evidence employed by scientists. A species of this error might be called judicial scientific overreaching. Judges might demand more substantiation than scientists themselves would for the task at hand. For example, recently some courts have required that experts must know the biological mechanism of harm before their

103. The assignment of burdens of proof refers to the party or scientists who must take the argumentative initiative in persuading other scientists that the evidentiary or knowledge status quo should be changed. Typically, the burden falls on those who argue that scientists are mistaken about what is currently known, that is, on those who would change the knowledge status quo. Standards of proof refer to the degree of certainty required to substantiate a claim, as established by scientific evidentiary norms and practices, that a person would have to meet who would argue to change the status quo ante. For a discussion of the legal ideas of burdens and standards of proof, see FLEMING JAMES, JR. \& GeOFFrey C. HAZARD, Civil PROCEDURE 249-62 (2d ed. 1977).

104. See Carl F. Cranor et al., Judicial Boundary Drawing and the Need for Context-Sensitive Science in Toxic Torts After Daubert v. Merrell Dow Pharmaceuticals, Inc. 16 VA. ENVTL. L.J. 1, 28-58 (1996).

105. Daubert v. Merrell Dow Pharms., Inc., 509 U.S. 579, 579 (1993).

106. An analogous problem would be mistaken restrictions on the kinds of experts who can contribute to the issues involved. 
testimony can be admitted. ${ }^{107}$ Moreover, some still appear to make epidemiological studies necessary conditions of admissibility. ${ }^{108}$

Explanatory mistakes will undermine the Supreme Court's aim in Daubert to ground more soundly legal decisions on reliable scientific methods. ${ }^{109}$ Courts have been sensitized to criticisms from the defense bar and the scientific community that the outcomes of some cases were not supported by appropriate scientific evidence. ${ }^{110}$ However, if they proceed to evaluate evidence in ways that violate sound and reliable evidence-assessment principles, this will raise anew the criticism that courts are not assessing scientific evidence well.

Another mistake would be for courts inadvertently to adopt standards for admissibility that enshrine misleading distributions of mistakes for torts. ${ }^{111}$ It is simply a fact of institutional life that legal and factual mistakes will result from imperfect institutions. Courts and scientists try to prevent them in their respective areas, but science and law differ as to which mistakes are the object of attention. The scientific concern is primarily to avoid factual false positives, while tort law is concerned equally with both factual false positives and factual false negatives that could contribute to legal mistakes. ${ }^{112}$

In General Electric Co. v. Joiner, Justice Breyer's concurring opinion noted a concern in the Federal Rules of Evidence with both truth and justice, but he suggests that truth is a necessary prerequisite for justice. ${ }^{113}$ However, if truth is a matter of the accurate avoidance of errors, as his remarks suggest, it matters what distribution of errors is the object of a court's attention in the search for accuracy. Courts should not be so concerned with factual false positives that tort law becomes distorted as an institution compared with procedures that utilized more sensitive admissibility rules. ${ }^{114}$ Admissibility standards that are insensitive to this issue and too demanding will impose a hidden factual burden of proof on plaintiffs, and increase their procedural hurdles before they can bring their full case before a jury. This risks upsetting the balance of interests be-

107. See Black v. Food Lion, Inc., 171 F.3d 308, 314 (5th Cir. 1997).

108. See Chambers v. Exxon Corp., 81 F. Supp. 2d 661 (M.D. La. 2000) (holding that expert testimony that benzene exposure causes chronic myelogenous leukemia ("CML") was inadmissible for lack of scientific reliability, in the absence of an epidemiological study that conclusively established a statistically significant risk of contracting CML from exposure to benzene (emphasis added)).

109. Daubert, 509 U.S. at 579.

110. There is a commonalty of interests here because defendants are defending their products from claims of harm, and scientific skepticism about evidence of harm fits nicely, if inadvertently, with such views.

111. The distribution of the risk of mistakes in the law is a matter of fairness or justice between parties as embedded in institutional norms, but such an idea is ordinarily out of place in science. There are risks of mistakes in science to be sure, but the notion of a "fair" or "just" distribution of the risks of making mistakes is inappropriate. Whatever the rationale for scientific practices protecting against mistakes, it is not a matter of justice.

112. See Walker, supra note 57, at 1115.

113. See General Elec. Co. v. Joiner, 509 U.S. 136, 148-49 (1997) (Breyer, J., concurring).

114. One can show in statistical studies, such as epidemiological or animal studies, that with less than ideal sample sizes, reducing the chances of false positives mathematically increases the chances of false negatives. See CRANOR, supra note 81, at 31-40. 
tween plaintiffs and defendants by imposing an unusually heavy burden of the risk of mistake on the moving party. ${ }^{115}$

Finally, and related to the previous issue, judges need to be sensitive to some of the more particular inferential mistakes experts can make that contribute to both factual false positives and factual false negatives. ${ }^{116}$ They also need to recognize legitimate patterns of evidence to which respectable scientists subscribe, some of which are considered below.

\section{$\mathrm{V}$ \\ PATTERNS OF EVIDENCE AND THE NEED FOR SENSITIVE ADMISSIBILITY RULINGS}

Courts need to understand not only the easy and obvious patterns of evidence that lead to conclusions that a substance can cause harm to humans, such as those available in the Bendectin cases. They must also understand more subtle, less usual, but still reliable, scientific patterns of evidence that implicate substances as likely harmful to humans.

\section{A. Judicial Screening of Evidence}

One can determine something about judicial screening of evidence from the reasoning in various district and appellate court cases. This information runs some risk of being superficial, however, because judges might have ruled correctly given the evidence but may have inaccurately described what they were doing. Nonetheless, ordinarily there are only written reasons to guide assessments. By this measure, it appears that some courts have had difficulty understanding aspects of scientific reasoning and inference, as well as some of the scientists' more specific instantiations on specific issues. Some courts have been captured by misleading ideas of scientific evidence and do not appear to have screened evidence well, ${ }^{117}$ while some other courts have. ${ }^{118}$

115. See Clayton P. Gillette \& James E. Krier, Risk, Courts, and Agencies, 138 U. PA. L. REV. 1027, 1043-61 (1990) (arguing before the Daubert decision, in the context of addressing concerns about "junk science," that procedural rules favoring plaintiffs, including causation rules, merely help to balance out a bias against plaintiffs in obtaining access to tort remedies). Gillette \& Krier also argued in 1990 that the overall balance of interests between plaintiffs and defendants appeared to be appropriate. See id. That has likely changed because of the way courts have interpreted Daubert. See Cranor et al., supra note 104 , at 24 .

116. Because of the way the debates about the evidentiary requirements following Daubert have evolved, and because of a greater concern in the scientific community with false positive than with false negative mistakes, judges may have developed a greater concern to avoid inferential mistakes that contribute to false positives than inferential mistakes that contribute to false negatives.

117. Some early decisions following Daubert manifested problems, and those problems may persist because of stare decisis. See e.g., Chambers v. Exxon Corp., 81 F. Supp. 2d 661, 664 (M.D. La. 2000) ("[T]he most conclusive type of evidence is epidemiological evidence. ... [P]laintiffs' experts have not offered an epidemiological study that conclusively establishes a statistically significant risk of contracting CML from exposure to benzene." (emphasis added)).

118. Examples include Zuchowicz v. United States, 140 F.3d 381 (2nd Cir. 1998); Holbrook v. Lykes Brothers Steamship Co., 80 F.3d 777 (3rd Cir. 1996); Ambrosini v. Labarraque, 101 F.3d 129 (D.C. Cir. 1996); McCullock v. Fuller, 61 F.3d 1038 (2nd Cir. 1995); In re Paoli R.R. Yard PCB Litig., 35 F.3d 717, 
A number of courts have substituted intuitive but mistaken inferences for good scientific reasoning about the evidence before them. For example, judges may reason, as many persons would when confronted with results from animal studies, that humans are not rats or mice, and thus results from rodent studies are not applicable to humans. ${ }^{119}$ Animal evidence is not perfect and mathematically certain for guiding the evaluation of the toxicity of substances for humans, but it can be good and reliable evidence. What is important about animals is not their size, shape, intelligence, or behavior, but their biology at the organ system, tissue, molecular, and genetic levels. Thus, however intuitively tempting the above inferences may be, they are overly simplistic and mistaken because animal and mechanistic studies are the foundation for much of toxicology. ${ }^{120}$ Those inferences are also contradicted by practice because reliance on animal studies is firmly embedded in corporate research, governmental policies and practices, and more than fifty years of basic and applied scientific research.

The time for mistaken judicial intuitions is past, however. The judiciary can no longer avoid becoming sufficiently sophisticated to recognize legitimate patterns of evidence. Litigants faced with detailed evidentiary gatekeeping by courts will only present more detailed and arcane rehearsals of evidence in admissibility hearings. When courts insist on detailed presentation of the scientific basis for testimony, this invites even more particular rebuttals and responses to the rebuttals. Some of this is inevitable, given the normal course of trials, but it has been exacerbated with the Supreme Court's Daubert mandate. However, if judges are not more broadly sensitive to scientific inferences, they will increasingly be unable to recognize mistaken claims made about scientific evidence. Furthermore, unless judges become more familiar with legitimate forms of scientific inference and reasoning, they are likely to be manipulated by litigants. In particular, skeptics about scientific inference are likely to win out by appealing to intuitive but mistaken pre-scientific reactions to evidence, such as the mistaken views that animal studies provide little or no evidence about the properties of chemical effects in humans or that mechanistic information is required. Strong skepticism reinforces the knowledge status quo, which is often simple ignorance about toxic properties.

780 (3d Cir. 1994), cert. denied, 513 U.S. 1190 (1995). For a recent district court case showing sensitivity to these issues, see Globetti v. Sandoz Pharms. Corp., 2000 WL 1279770 (N.D. Ala. Sept. 6, 2000).

119. Consider two such cases: Plaintiff's expert relied on a study of the effect of picloram on rats that showed that when exposed to large amounts of the chemical, the rats developed cancerous tumors and died. He admitted that the effects of chemicals differ between humans and rats .... We then are left to conclude that the study, at most, is only evidence that picloram may produce some unidentified effect on humans.

Viterbo v. Dow Chem. Co., 826 F.2d 420, 424 (5th Cir. 1987). "The animal studies are not helpful in the instant case because they involve different biological species. They are of so little probative force and are so potentially misleading as to be inadmissible." In re Agent Orange Prod. Liab. Litig., 611 F. Supp. 1223, 1241 (E.D.N.Y. 1985).

120. See Shayne C. Gad, Model Selection and Scaling, in ANIMAL Models IN ToxiCOLOGY 813 (Shayne C. Gad \& Christopher P. Chengelis eds., 1992). 
Moreover, judicial failure to recognize some of the subtleties of scientific reasoning will undermine the authority of the law because of critiques of judicial gatekeeping. A growing body of scholarly literature is critical of judicial review of scientific evidence. ${ }^{121}$ Under the guise of mere procedural changes, this has affected substantive law, changed the relationship between judge and jury, and shifted the scales of justice against injured parties in the post-market context of torts. ${ }^{122}$ Perhaps not all of these concerns can be addressed by more sensitive treatment of scientific evidence, but some can.

\section{B. Mistakes of Concern}

As a preliminary point, is it reasonable to ask what is the appropriate principle for rejecting some evidence as inadmissible? Based upon Daubert ${ }^{123}$ (with some modification in Joiner ${ }^{124}$ and $K u m h o^{125}$ ), the principle appears to be that evidence that is probably either not "reliable" or not grounded "in the methods and procedures of science" should be excluded. ${ }^{126}$ According to Daubert, when courts determine the admissibility of evidence, they should ask whether the evidence was more likely than not based upon the scientific methods and procedures. ${ }^{127}$ If the answer is no, the evidence should be excluded. If the answer is yes-that the evidence probably resulted from scientific reasoning-then it should be admitted. Although courts have considerable latitude in screening evidence, if the questions are framed properly, the answers to them appear to be more determinate than some appellate opinions suggest. The reason for this is that scientists utilize certain categories of evidence to come to their conclusions: epidemiological evidence, if it is available, animal studies, various shortterm toxicity, and mechanistic studies. If a particular scientist relies on such evidence and evaluates it as do other respectable scientists, but assigns somewhat different weight to it, a respectable scientist more likely than not has followed scientific reasoning and procedures, even if her conclusions are not necessarily in accord with other experts' conclusions. Thus, it may be more difficult than courts have suggested to show that an expert's reasoning is probably not reflective of scientific procedures and methods. This is especially the case when a suitably wide range of respectable views is recognized. Scientific experts do disagree, even when evaluating the same evidence. ${ }^{128}$ Different experts may weigh particular pieces of evidence differently or have different legitimate

121. See Berger, supra note 3; Finley, supra note 3; Graham, supra note 3; Green, supra note 3; Ozonoff, supra note 3.

122. Margaret G. Farrell, Daubert v. Merrell Dow Pharmaceuticals, Inc.: Epistemiology and Legal Process, 15 CARDOZO L. REV. 2183 (1994); Finley, supra note 3; Green, supra note 3.

123. Daubert v. Merrell Dow Pharms., Inc., 509 U.S. 579, 579 (1993).

124. General Elec. Co. v. Joiner, 522 U.S. 136, 136 (1997).

125. Kumho Tire Co., Ltd. v. Carmichael, 526 U.S. 137, 137 (1999).

126. Daubert, 509 U.S. at 588.

127. Id. at 589-90.

128. See infra note 167. 
background assumptions that lead to somewhat different conclusions, but all may be following the methods, procedures, and reasoning of science. ${ }^{129}$

One problematic issue is that some courts have insisted on an epidemiological threshold in toxic tort cases. ${ }^{130}$ Such rulings in toxic tort cases have both preceded $^{131}$ and followed ${ }^{132}$ the Daubert decision. Other courts have rightly disagreed with this approach. ${ }^{133}$ Moreover, a substantial body of scholarly literature criticizes this practice, so it need not be reviewed further here. ${ }^{134}$ Legal experts recommend against an epidemiological threshold, scientists do not endorse it, and even corporate experts do not endorse it in product develop-

129. Not all judicial rulings on scientific evidence raise issues of toxicology. Some merely deal with correctly assessing circumstantial evidence involving exposures to toxic substances. These are not addressed here, but for examples see Moore v. Ashland Chemical, Inc., 151 F.3d 269 (5th Cir. 1998) (considering the adequacy of circumstantial and scientific evidence that exposure to a spilled solvent caused respiratory tract disorders), Wright v. Willamette Indus., Inc., 91 F.3d 1105 (8th Cir. 1996) (concerning circumstantial and scientific evidence that exposure to formaldehyde-impregnated wood dust caused respiratory disorders). Cf Zuchowicz v. United States, 140 F.3d 381, 389-91 (2d Cir. 1998) (opinion of Judge Calabresi).

130. See Green, Expert Witnesses, supra note 24, at 674-80; see also Cranor et al., Judicial Boundary Drawing, supra note 104, at 54; Green, supra note 3, at 398.

131. A few courts limited this view to Bendectin cases, see Daubert v. Merrell Dow Pharms., 727 F. Supp. 570, 572 (S.D. Cal. 1989), aff'd, 951 F.2d 1128 (9th Cir. 1991), while others did not, see Renaud v. Martin Marietta Corp., 749 F. Supp. 1545 (D. Colo. 1990) (holding that, in a case concerning exposures to hydrazine and trichloroethylene (both known or probable human carcinogens), among others, plaintiffs were required to submit epidemiological evidence in support of their causation contentions). See Thomas v. Hoffman-La Roche, Inc., 731 F. Supp. 224, 228 (N.D. Miss. 1989), aff'd on other grounds, 949 F.2d 806 (5th Cir. 1992) ("[w]ithout some epidemiological study or statistical basis for the expert's opinion ... the opinion as to causation amounts to little more than speculation."); Carroll v. Litton Sys., Inc., No. BC - 88-253, 1990 U.S. Dist. LEXIS 16,833, at *138 (W.D.N.C. Oct. 29, 1990).

132. See Chambers v. Exxon Corp., 81 F. Supp. 2d 661 (M.D. La. 2000) (citing Brock v. Merrell Dow Pharms., Inc., 874 F.2d 307, 311 (5th Cir. 1989)), modified by, 874 F.2d 307, 311 (5th Cir. 1989); WadeGreaux v. Whitehall Labs., Inc., 874 F. Supp. 1441 (D.V.I. 1994). See generally MiCHAEL D. GREEN, BENDECTIN AND BIRTH DEFECTS, supra note 23, at 311-17 (arguing that Bendectin and Agent Orange cases should not be generalized to other toxic agents); Cranor et al., supra note 104, at 31-32 (reviewing Agent Orange, Bendectin, and several other cases invoking an epidemiologic threshold); Finley, supra note 3, at 352-56 (noting that courts have adopted epidemiological thresholds in silicone breast implant cases).

133. See, e.g., In re Paoli R.R. Yard PCB Litig., 35 F.3d 717 (3d Cir. 1994); Hines v. Consol. Rail Corp., 926 F.2d 262, 271 (3d Cir. 1991); Villari v. Terminix Int'l, Inc., 692 F. Supp. 568, 572 (E.D. Pa. 1988). The Paoli court provided helpful discussion, as it relied on In re Bendectin Product Liab. Litigation, 732 F. Supp. 744, 749 (E.D. Mich. 1990) (noting that experts in the field think it is reasonable to rely on non-epidemiological studies to link Bendectin to birth defects). See also Hagen v. RichardsonMerrell, 697 F. Supp. 334, 337 (N.D. Ill. 1988) (holding defendants did not adequately demonstrate that expert opinion based partly on animal studies should be excluded); Rubanick v. Witco Chem. Corp., 576 A.2d 4, 7, 15 (N.J. Super. 1990) (reversing trial court's exclusion of expert testimony under New Jersey law, which was partly based on animal studies that PCBs caused cancer).

In Villari v. Terminix Int'l. Inc., 692 F. Supp. 568, 570 (E.D. Pa. 1988), Judge Pollak explained that

while it may be true that defendant can offer tests and experiments that do not support the findings of plaintiffs' expert, the defendant cannot deny that animal studies are routinely relied upon by the scientific community in assessing the carcinogenic effects of chemicals on humans. Even the defendant's own expert acknowledges that animal experiment studies are built on "prudent presumptions," although he concludes that they should not be admitted.

134. See GREEN, BENDECTIN \& BIRTH DEFECTS, supra note 24, at 311-17; Cranor et al., supra note 104, at 31; Green, Expert Witnesses, supra note 24, at 678-80; Green, supra note 3, at 398. 
ment. ${ }^{135}$ Thus, except in special circumstances, a court that insists on this evidentiary threshold would appear to be making a clearly erroneous judgment, which should invite an appellate court to overturn such a ruling on appeal. In addition, there have been judicially mandated requirements on epidemiological studies and their interpretation that are contrary to evidence evaluation that scientists themselves would endorse. ${ }^{136}$

Good human evidence should take precedence over other forms of evidence if it is available, which is frequently not the case. ${ }^{137}$ Human evidence, including clinical evidence, human case reports, and human pathological studies, is broader than epidemiological evidence. ${ }^{138}$ Moreover, good epidemiological studies must be well designed and of sufficient quality to preclude both false positives and false negatives. ${ }^{139}$

In most cases, litigants will have difficulty presenting sufficiently good epidemiological evidence for a case to be determined by epidemiological data alone or for epidemiological studies to have priority over all other kinds of toxicological data. ${ }^{140}$ Once courts recognize this, they need to recognize and be willing to admit other patterns of toxicological evidence that are endorsed by the scientific community. In addition, other kinds of evidence may cast doubt on-or further support-human evidence. ${ }^{141}$

Moreover, an understanding of the stringent requirements on epidemiological studies makes apparent how to tailor a study that would lead to results favorable to a litigant. Studies that utilize samples that are too small, that are of too short a duration for the disease in question, that have poor exposure data, or that have classification biases of the exposed versus the non-exposed would likely fail to detect the disease of concern. Studies that did not rule out selection or recall bias, chance, or confounding factors could be falsely positive. ${ }^{142}$

135. See International Conference on Harmonisation of Technical Requirements for Registration of Pharms. for Human Use, ICH Harmonised Tripartite Guidline: Guidline on the Need for Carcinogenicity Studies of Pharmaceuticals 2 (Nov. 1995) (visited Apr. 23, 2001) <http:॥www.ifpma.org /pdfifpma/s1a.pdf $>$.

136. See Cranor et al., supra note 104, at 37-49 (noting that some courts have insisted on epidemiological studies exhibiting a relative risk of at least two in order to be recognizable as admissible as the foundation of expert testimony, which ignores those whose individual risk may be greater than two, such as those in susceptible subpopulations, and highly exposed individuals).

Some courts have demanded that epidemiological studies exhibit statistical significance at the .05 level without sensitivity to issues of varying the cutoff of statistical significance, although this risks increasing type II errors. See id.

137. See Tomatis et al., supra note 30, at 99-101.

138. For a recent discussion of some of these points, see Globetti v. Sandoz Pharms. Corp., 111 F. Supp. 2d 1174 (N.D. Ala. 2000).

139. This article does not review these studies because it has been done by others. See Green et al., supra note 98 , at 333-40.

140. See David P. Rall et al., Alternatives to Using Human Experience in Assessing Health Risks, 8 ANN. ReV. Publ. Health 355, 362-63 (1987) (noting that for most chemicals, particularly environmental and occupational chemicals, epidemiologic data are insufficient to confirm the absence or presence of significant risk).

141. See id. at 356.

142. See Michael Green et al., Reference Guide on Epidemiology, in FEDERAL REFERENCE MANUAL ON SCIENTIFIC EVIDENCE, supra note 3, at 333, 356-73 (discussing the features of good epi- 
Other inferences that courts have endorsed are also problematic. For example, courts have had difficulty ruling on the probity of animal studies to human harm. ${ }^{143}$ In addition, some courts in toxic tort cases have required litigants to present evidence of the mechanism or "physiological process by which a particular disease or syndrome develops." ${ }^{144}$ While courts might have ruled properly in rejecting all the evidence taken together in particular cases, their insistence that the physiological mechanism must be understood before evidence is admitted or legal causation can be established is especially problematic. For example, even for such a well-known and well-studied substance as aspirin, scientists have limited understanding of the mechanisms of either therapeutic or toxic effects. ${ }^{145}$ For a substance such as benzene, toxicologists are still searching for the mechanism by which it causes cancer, even though for some time it has been a known human carcinogen. ${ }^{146}$ While mechanistic evidence can be quite helpful in determining the etiology of disease, it would be rare that scientists would have an understanding of the mechanistic pathways of a toxicant in tort cases. ${ }^{147}$ There may be a contrast on this point between some viral or bacterial diseases, which leave trace data, and those caused by toxic substances, which rarely leave detectable traces. ${ }^{148}$

The idea of a disease mechanism is merely an instance of a much larger point that may pose problems: Evidence can be asymmetrically probative. ${ }^{149}$

demiological studies, including statistical significance, bias, and confounding); Tomatis et al., supra note 30, at 99-101 (discussing some weaknesses in using epidemiology to identify environmental health problems).

143. See supra note 118 and accompanying text.

144. Black v. Food Lion, Inc., 171 F.3d 308, 314 (5th Cir. 1999):

The underlying predicates of any cause-and-effect medical testimony are that medical science understands the physiological process by which a particular disease or syndrome develops and knows what factors cause the process to occur. Based on such predicate knowledge, it may then be possible to fasten legal liability for a person's disease or injury..

In Schudel v. General Electric Co., 120 F.3d 991, 997 (9th Cir. 1997), the court suggested a similar reason for rejecting evidence, although it was not central to its rejection, noting that one of plaintiff's experts acknowledged that the biochemical mechanism of neurotoxicity from trichloroethane and perchloroethylene had not been demonstrated.

145. See Santone \& Powis, supra note 44, at 169.

146. See David A. Eastmond, Benzene Induced Genotoxicity: A Different Perspective, $61 \mathrm{~J}$. TOXICITY \& ENVTL. HEALTH 353 (2000).

147. Consider the case of aspirin, a particularly well-studied substance. If the mechanisms of aspirin are poorly understood, it is unlikely that the mechanisms of other substances are. See Santone \& Powis, supra note 44, at 169.

148. Bacterial and viral infections leave evidence of the causal agent, but only in unusual cases, such as asbestos (leaving fibers behind) or substances that cause very high relative risks such as diethlystilbestrol ("DES") or vinyl chloride, is there a signature of the disease.

149. The point about asymmetrically probative evidence is illustrated by reference to a discussion of a State of California science advisory panel document. See Electric and Magnetic Fields Risk Evaluation Guidelines 18 (California Department of Health Services, Dec. 1999). The document analyzes the likelihood of observing certain patterns of evidence if a substance, such as thalidomide, causes birth defects and does not cause birth defects, respectively.

Babies without arms or legs were born to women who had taken thalidomide in early pregnancy. So, the question was raised:

[W] hat evidence was available at the time on molecular structure and function, metabolic knowledge animal tests and epidemiology? The likelihood that a small epidemic of specific 
Evidence may support an inference of toxicity if it is present, but its absence does not mean that one cannot conclude that the substance is toxic to humans. ${ }^{150}$ Thus, for example, there is considerable knowledge that some substances are human carcinogens, but for most of them, there is little understanding of the complete molecular and physiological processes by which they are toxic. ${ }^{151}$ Mechanistic evidence helps support an inference that a substance is toxic, but its absence is quite consistent with a substance being toxic. ${ }^{152}$ By analogy, good and reliable eyewitness testimony in either criminal or civil cases may greatly support a complainant's evidentiary case-perhaps making it conclusive-but the absence of such testimony does not preclude a good evidentiary case.

Some courts have ruled that an expert cannot rely on a rat study for evidence of toxicity in humans where the results could not be replicated in mice. ${ }^{153}$ This too is problematic. While there tends to be general concordance between these two phylogenetically close species, there is no necessity for it. Substances may well be toxic in one or more species, but not others, and still be toxic to humans. ${ }^{154}$ The underlying principle is that different species may show different toxic effects to a greater or lesser degree. Rats may be more or less susceptible to a given toxicant than mice. ${ }^{155}$ For example, both the human carcinogens Direct Black 38 and Direct Blue 6 are carcinogenic in rats but not in mice under

birth defects would appear after the introduction of thalidomide is quite a bit larger if thalidomide is hazardous than if it is safe, [s]o one's degree of confidence of hazard increases quite a bit after reviewing the epidemic. This is particularly so when one notes that the medication was taken at the vulnerable time of development of the fetal arms and legs.

Examining the molecular structure of the agent did not suggest a mechanism for a hazard, but the likelihood of having that kind of explanation even if it were hazardous is small, though relatively larger than if the agent were safe. If one had a theory, it would boost one's degree of confidence, but the absence of theoretical mechanism doesn't pull down one's degree of confidence much.

Animal studies did not show thalidomide to cause birth defects at first. But the likelihood that something that causes birth defects in humans will do so in any given species of rodent is not very high, though higher than would be the case if the agent did not cause birth defects in humans. So once again this stream of evidence can strengthen one's degree of confidence if one gets a positive result, but doesn't pull it down much if one gets a negative result.

What is the net result? Before one heard about the epidemic, one's initial degree of confidence that $[t]$ halidomide would cause birth defects was quite small . . . That is because there are many medicines that are taken during pregnancy and only a tiny minority have ended up causing birth defects. The lack of mechanistic reasons and the negative animal study pulls that degree of confidence down, but not very much. The coherent epidemiological findings with big effects are relatively much more likely if [t]halidomide is a hazard than if it is safe, and that pulls the degree of confidence up much more than the other streams of information pulled it down. So one ends up with a "highly probable" to "virtually certain" degree of conId. fidence that $[\mathrm{t}]$ halidomide causes birth defects.

150. See id.

151. See id.

152. See id.

153. See Allen v. Pennsylvania Eng'g Corp., 102 F.3d 194, 197 (5th Cir. 1996).

154. See Gad, supra note 120 , at 841,849 \& tbls. 5, 6 .

155. See id. 
the same experimental conditions and routes of exposure. ${ }^{156}$ MPTP-1-methyl4-phenyl-1,2,3,6-tetrahydropyridine-a chemical causing a Parkinson's diseaselike condition in humans, induces a similar neurotoxic effect in mice, but not in rats. ${ }^{157}$ In addition, melphalan, a human carcinogen, is positive in rhesus monkeys and negative in the phylogenetically similar cynomologous monkeys. ${ }^{158}$ If substances are carcinogenic in two species, the probability that they are carcinogenic in humans is increased; but a substance might be quite potent and harmful to humans even though it did not result in carcinogenicity in at least two rodent species. Frequently, substances have not been tested, or not adequately tested, in other species. Toxicologists design studies to have the best chance of detecting toxic results that are pertinent to humans. ${ }^{159}$

Judges will confront a general criticism that because the target sites of cancer in animals are different from the target sites in humans, this cannot be evi-

156. U.S. DEPARTMENT OF HEAlth AND Human SERVICES, NATiOnAl Toxicology PROGRAM, NinTH ANNUAL REPORT ON CARCINOGENS (last modified Oct. 20, 2000) $<\mathrm{http}: / /$ his.niehs.nih.gov/roc/ninth/known.pdf $>$.

157. See Richard E. Heikkila et al., Dopaminergic Neurotoxicity of 1-Methyl-4-Phenyl-1,2,5,6Tetrahydropyridine in Mice, 224 SCIENCE 1451, 1451-53 (1984); Rajesh N. Kalaria et al., Correlation of 1-Methyl-4-Phenyl-1,2,3,6-Tetrahydropyridine Neurotoxicity with Blood-Brain Barrier Monoamine Oxidase Activity, 84 ProceEdings ACAD. SCI. U.S. AM. 3521-25 (1987).

158. See Summary of Carcinogenic Potency Database by Chemical: Nonhuman Primates and Dogs (visited Feb. 2, 2001) <ftp://potency.berkeley.edu/pub/tables/chemicalsummary.other.text>.

159. The literature on these issues is substantial. See Gad, supra note 120, at 813-40. This entire book is directed at the premises that (1) animals can serve as accurate predictive models of toxicity in humans (or other species); (2) the selection of an appropriate species to use is key to accurate prediction in man; and (3) understanding the strengths and weaknesses of any particular model is essential to understanding the relevance of specific target organ toxicities to what would be expected in humans.

A fundamental hypothesis of toxicology is that adverse effects caused by chemical entities in animals are generally the same as those induced by those entities in humans. Many scholars point to individual exceptions to this, and conclude that the general principle is false. Yet, as our understanding of molecular biology advances and we learn more about the similarities of structure and function of higher organisms at the molecular level, the more it becomes clear that the mechanisms of chemical toxicity are largely identical in humans and animals. See id. at 813.

Other experts and the EPA concur. See Romualdo Benigni \& Alessandro Giuliani, Tumor Profiles and Carcinogenic Potency in Rodents and Humans: Value for Cancer Risk Assessment, ENVTL. CARCinogenesis \& ECTOTOXICOLOGY ReVIEWS-PART C J. ENVTL SCI. \& HeAlTH 45, 63 (1999) (reporting that key information concerning the probity of animal evidence for human cancer lies in carcinogenic potency, not in the specificity in the response of a species); Environmental Protection Agency Proposed Guidelines for Carcinogen Risk Assessment, 61 Fed. Reg. 17,960, 17,967, 17,977 (1996) [hereinafter U.S. EPA, Proposed Guidelines for Carcinogen Risk Assessment]; see also Michael P. Waalkes et al., The Scientific Fallacy of Route Specificity of Carcinogenesis with Particular Reference to Cadmium, 20 Reg. TOXICOLOGY \& PHARMACOLOGY 119 (1994):

[T] he mechanisms of control of cell growth and differentiation are remarkably homologous among species and highly conserved in evolution .... Thus far, there is evidence that growth control mechanisms at the level of the cell are homologous among mammals, but there is no evidence that these mechanisms are site concordant. Moreover, agents observed to produce tumors in both humans and animals have produced tumors either at the same (e.g., vinyl chloride) or different sites (e.g., benzene) (NRC, 1994). 
dence for carcinogenicity in humans. ${ }^{160}$ This view is tempting, but mistaken. ${ }^{161}$ For example, benzidine is a known human bladder carcinogen, but is not a bladder carcinogen in animal species (except for dogs), although it induces tumors in other tissues, such as hamsters (liver tumors), rats (liver, earduct, mammary, and intestinal tumors), and mice (liver tumors). ${ }^{162}$ Moreover, there appears to be no scientific agreement that there must be tissue concordance between animals and humans. ${ }^{163}$ Concordance in tumor sites, while considerably strengthening the evidence, is not essential.

As indicated above, the results of well-conducted animal tests can provide reliable evidence for the toxicity and carcinogenicity of chemical and physical agents. These results need to be evaluated carefully, however, for reproducibility and relevance to humans. Bioassays involving the use of high doses and the evaluation of large numbers of tissues, as well as the testing of strains of laboratory animals prone to high incidences of spontaneous tumors, can produce results that may not be reproducible or likely to occur in humans under normal exposure conditions. ${ }^{164}$ They may be directly pertinent to workers, however, or those subject to accidental exposures. In addition, there is a growing consensus that a few classes of chemical agents induce tumors in animals through mechanisms that do not operate in humans. ${ }^{165}$ Therefore, it is unlikely that these agents would cause cancer in humans.

\section{Toxicologically Reliable Patterns of Evidence}

A wide range of evidentiary patterns implicates substances as carcinogenic to humans. The discussion that follows reviews several patterns of evidence for carcinogens, taken from the scientific literature, on which there is a substantial consensus that one can infer the certainty or likelihood of human harm. These are meant to serve as examples of kinds and patterns of evidence that a substance probably causes cancer in humans.

160. See, e.g., David E. Berstein, The Admissibility of Scientific Evidence After Daubert v. Merrell Dow Pharmaceuticals, Inc., 15 CARDOZO L. REV. 2139, 2167 (1994); Allen v. Pennsylvania Eng'g Corp., 102 F.3d 194, 197 (5th Cir. 1996) (holding that animal studies are too unreliable). For a general discussion of this issue, see James Huff, Applicability to Humans of Rodent-Specific Sites of Chemical Carcinogenicity: Tumors of the Forestomach and of the Harderian, Preputial, and Zymbal Glands Induced by Benzene, 1 J. OCCUPATIONAL MED. \& TOXICOLOGY 109-41 (1992).

161. See James Huff, Long-Term Chemical Carcinogenesis Bioassays Predict Human Cancer Hazard: Issues, Controversies and Uncertainties, 895 ANNALS N.Y. ACAD. SCI. 56, 62 (1999); U.S. EPA, Proposed Guidelines for Carcinogen Risk Assessment, supra note 159, at 17, 977.

162. See I TOXICOLOGICAL RISK AsSESSMENT: BIOLOGICAL AND STATISTICAL CRITERIA 105-22

(D.B. Clayson et al. eds., 1985).

163. See supra note 161.

164. Animals are exposed to high doses to overcome problems of small sample sizes typically used in animal bioassays. See National Research Council, supra note 39, at 24-27; see also OTA, IDENTIFYING AND REGULATING CARCINOGENS, supra note 5, at 39, 46.

165. See IARC, Preamble to the IARC Monographs (last modified Aug. 9, 2000) <http:// 193.51.164.11/monoeval/preamble.html>; NINTH ANNUAL REPORT ON CARCINOGENS, supra note 156; Jerry M. Rice et al., Rodent Tumors of Urinary Bladder, Renal Cortex, and Thyroid Gland in IARC Monographs Evaluations of Carcinogenic Risk to Humans, 49 TOXICOLOGICAL SCI. 166 (1999). 
In several respects, even these examples are too robust to serve as evidentiary models for admissibility decisions. Plaintiffs' experts need only show that the foundation for their testimony is "more likely than not reliable," not that it is probably correct. ${ }^{166}$ The patterns that follow, however, are models of evidentiary support for an ultimate conclusion that a substance is either a known human carcinogen or more likely than not a human carcinogen. Moreover, they represent peer-reviewed and (in most cases) consensus judgments (something not required for admissibility), and the patterns are taken from comparatively cautious and respectable scientific bodies. Thus they do not represent the range of views respectable scientists might have of the same scientific evidence. ${ }^{167}$ These patterns of evidence are sufficient as models for a reliability judgment.

The IARC currently lists fifty-four agents and groups of agents that are carcinogenic to humans (excluding twenty-five mixtures and exposure circumstances). ${ }^{168}$ Most of these have good human epidemiological evidence to support that claim. ${ }^{169}$ However, this is not true for two substances and one form of radiation. ${ }^{170}$ In addition, the National Toxicology Program lists Direct Black 38 and Direct Blue 6 as known to be human carcinogens, but there is no direct epidemiological evidence to support either assessment. ${ }^{171}$

Available human epidemiological evidence is not sufficient to establish a causal relationship between exposure to these substances and human cancer. For two of these five substances-ethylene oxide ("ETO") ${ }^{172}$ and 2,3,7,8tetrachlorodibenzo-para-dioxin ("dioxin"), ${ }^{173}$ evidence of carcinogenicity is limited. That is, "a positive association has been observed between exposure to the agent ... and cancer for which a causal interpretation is considered ... to be credible, but chance, bias or confounding could not be ruled out with reason-

166. See Michael H. Graham, The Expert Witness Predicament: Determining "Reliable" Under the Gatekeeping Test of Daubert, Kumho and Proposed Amended Rule 702 of the Federal Rules of Evidence, 54 U. MIAMI L. REV. 317, 336-46 (2000).

167. For a sense of how experts reviewing identical evidence might disagree, see NATIONAL INST. of ENVTl. HeAlth SCIENCES, National Inst. OF HeAlth No. 99-4493, HeAlth EfFects from EXPOSURE TO POWER-LINE FREQUENCY ElECTRIC AND MAGNETIC FIELDS (Christopher J. Portier \& Mary S. Wolfe eds., 1998). The Working Group of about 30 voted on what conclusions they drew from each piece of evidence, but the votes were not unanimous and sometimes were sharply divided. See id.

168. See IARC, Overall Evaluation of Carcinogenicity to Humans, Group 1: Carcinogenic to Humans (last modified May 31, 2000) <http://193.51.164.11/monoeval/crthgr01.html $>$.

169. See IARC, List of IARC Evaluations (last modified Aug. 9, 2000) <http://193.51.164.11/ monoeval/grlist.html>.

170. See id.

171. See Ninth ANNUAl RePORT ON CARCINOGENS, supra note 156.

172. Ethylene oxide has been produced since the early 1900s and is used as a chemical intermediate in the production of ethylene glycol, glycol ethers, and other industrial chemicals. It also serves as a sterilizing agent in hospitals. See IARC, Supplement Seven (last modified Aug. 26, 1997) <http:// 193.51.164.11/htdocs/Monographs/Vol60/M60-02.htm>.

173. See Polychlorinated Dibenzo-para-Dioxins (last modified Aug. 12, 1997) <http://193.51.164.11/ htdocs/monographs/Vol69/dioxin.html>. 
able confidence." ${ }^{174}$ And for three-neutron radiation, Direct Black 38 and Direct Blue 6, there is no direct human epidemiological evidence.

In all five cases, evidence of carcinogenicity in animals, and additional supporting evidence, led the scientific body to conclude that these substances were human carcinogens. ${ }^{175}$ ETO is an alkylating agent, which means that it places an alkyl chemical group on the DNA and induces genetic mutations and chromosomal breakage in a wide range of species. ${ }^{176}$ Dioxin is a multi-site carcinogen in experimental animals that acts through a receptor-mediated mechanism in cells that is believed to be common to animals and humans. ${ }^{177}$ Neutron radiation causes similar tissue and genetic damage to that of x-rays and gamma rays, forms of radiation known to cause human cancer. ${ }^{178}$ Direct Black 38 and Direct Blue 6 are metabolized in animals and humans to benzidine, a known human carcinogen. ${ }^{179}$

174. IARC, Preamble to the IARC Monographs, Section 12 (last modified Jan. 5, 1999) <http:// 193.51.164.11/monoeval/Eval.html>.

175. See IARC, supra note 169.

176. See IARC, supra note 165, at 108. "There is limited evidence in humans for the carcinogenicity of ethylene oxide," while "[t]here is sufficient evidence in experimental animals for the carcinogenicity of ethylene oxide." Id.

In making the overall evaluation, the Working Group took into consideration the following supporting evidence. Ethylene oxide is a directly acting alkylating agent that: (i) induces a sensitive, persistent dose-related increase in the frequency of chromosomal aberrations and sister chromatid exchange in peripheral lymphocytes and micronuclei in bone-marrow cells of exposed workers; (ii) has been associated with malignancies of the lymphatic and haematopoietic system in both humans and experimental animals; (iii) induces a dose-related increase in the frequency of haemoglobin adducts in exposed humans and dose-related increases in the numbers of adducts in both DNA and haemoglobin in exposed rodents; (iv) induces gene mutations and heritable translocations in germ cells of exposed rodents; and (v) is a powerful muId. tagen and clastogen at all phylogenetic levels.

\section{See Polychlorinated Dibenzo-para-Dioxins, supra note 173.}

There is limited evidence in humans for the carcinogenicity of 2,3,7,8-tetrachlorodibenzopara-dioxin .... There is sufficient evidence in experimental animals for the carcinogenicity of $2,3,7,8$-tetrachlorodibenzo-para-dioxin.... In making the overall evaluation, the Working Group took into consideration the following supporting evidence: (i) 2,3,7,8-TCDD is a multisite carcinogen in experimental animals that has been shown by several lines of evidence to act through a mechanism involving the Ah receptor; (ii) this receptor is highly conserved in an evolutionary sense and functions the same way in humans as in experimental animals; (iii) tissue concentrations are similar both in heavily exposed human populations in which an increased overall cancer risk was observed and in rats exposed to carcinogenic dosage regimens Id. in bioassays.

178. See IARC, Neutrons (last modified Apr. 19, 2000) <http://193.51.164.11/htdocs/monographs/ Vol75/Neutrons.html>.

179. This listing is based on the following observations: (1) benzidine is a known human carcinogen ...; (2) metabolism of benzidine-based dyes [including Direct Blue 6] to release free benzidine is a generalized phenomenon in humans and all experimental animal species studies, ... (3) benzidine exposure from exposure to benzidine-based dyes is equivalent to exposure to equimolar doses of benzidine. . . ; and (4) all available evidence indicated benzidine-based dyes are animal carcinogens and represent a carcinogenic risk to humans. There are no epidemiology studies available to assess the human carcinogenicity of direct blue 6 alone. Ninth Annual Report on Carcinogens, supra note 156, available at $<\mathrm{http}$ ///ehis.niehs.nih.gov/roc/ninth/known/benzidine-based_dyes.pdf $>$. Similar reasoning supports the judgment that Direct Black 38 is a human carcinogen. See id. 
These cases are counterexamples to the claim that human epidemiological evidence is a necessary condition for concluding that a substance is a known carcinogen. They also illustrate the importance of animal and other kinds of evidence to support such conclusions. All are based on multiple good animal studies together with other kinds of evidence. The evidence taken as a whole is sufficient for scientists to conclude unequivocally that each of the five is a human carcinogen. In addition, it is important to emphasize that these conclusions as to causation are inferential in nature; courts should not expect more. All toxicological judgments about causation are inferential, even those resting on epidemiological studies. The five just mentioned are more clearly so because they involve piecing together different kinds of evidence, a task a court typically finds itself required to undertake in other areas. Finally, the various patterns of evidence are different from each other, but lead to the same conclusion-the substance is carcinogenic to humans.

Second, consider several substances that the IARC classifies as probable human carcinogens. For 1-3 butadiene, ${ }^{180}$ tetrachloroethylene, ${ }^{181}$ trichloroethyl$e^{e n}{ }^{182}$ and formaldehyde, ${ }^{183}$ there is limited evidence of carcinogenicity in humans and sufficient evidence of carcinogenicity in animals. In these cases, animal evidence and "other data relevant to the evaluation of carcinogenicity and its mechanisms" 184 have provided reasons for the scientific body to judge that the substance probably is carcinogenic in humans. For each of these, human evidence contributed, but was not decisive; evidence of carcinogenicity in rodent studies plus some other evidence was critical. ${ }^{185}$

180. 1,3-Butadiene is used in high volume in the manufacture of a wide range of polymers, including styrene-butadiene rubber, polybutadiene, nitrile rubber, acrylonitrile-butadiene-styrene resins and styrene-butadiene latexes. It is also an intermediate in the production of various other chemicals. See IARC, Monograph SERIES No. 71, Re-EVAluation of SOME ORganic ChEMICALS, HydraZINE AND HYDROGEN PEROXIDE 109 (1999).

181. See IARC, Monograph Series No. 63, Dry Cleaning, Some Chlorinated Solvents AND OTHER INDUSTRIAL CHEMICALS 159 (1995).

182. See id. at 75.

183. See IARC, Monograph Series No. 62, WoOd Dust ANd FormaldeHyde 217 (1995) ("Taken together, the epidemiological studies suggest a causal relationship between exposure to formaldehyde and nasopharyngeal cancer, although the conclusion is tempered by the small numbers of observed and expected cases in the cohort studies ... . Because of the lack of consistency between the cohort and case-control studies, the epidemiological studies can do no more than suggest a causal role of occupational exposure to formaldehyde in squamous-cell carcinoma of the nasal cavities and paranasal sinuses.").

184. IARC, Overall Evaluations of Carcinogenicity to Humans: Probably Carcinogenic to Humans (last modified Aug. 9, 2000) <http://193.51.164.11/monoeval/crthgr02a.html>.

185. See id. 
For $\mathrm{MOCA}{ }^{186}$ for an anti-cancer drug 1-(2-chloroethyl)-3-cyclohexyl-1nitrosourea (CCNU), ${ }^{187}$ and for benzidine-related dyes, ${ }^{188}$ there is inadequate evidence $^{189}$ of carcinogenicity in humans and sufficient evidence of carcinogenicity in animals. IARC and the NTP classify these substances as probable human carcinogens. ${ }^{190}$ Here, traditional human epidemiological evidence did not directly contribute much to the judgment that the substance is a likely human carcinogen. That inference is based upon evidence from animals, human and animal studies of agents with similar properties, and additional supportive evidence. CCNU and benzidine-related dyes, two of which are described above, are especially interesting because they illustrate the importance of chemical structure-biological activity relationships in providing evidence for human carcinogenicity, even when there is inadequate human evidence. ${ }^{191}$

These are not isolated cases, but rather are representative of numerous others and merely serve to illustrate the larger points. The IARC lists fifty-four substances or groups of substances, excluding mixtures and exposure conditions, as probable human carcinogens. ${ }^{192}$ For about forty of these substances, evidence of carcinogenicity in humans is inadequate or limited. ${ }^{193}$ Nonetheless, the overall classification is based on sufficient evidence in animal studies plus

186. MOCA is 4,4'-methylenebis(2-chloroaniline). IARC's overall evaluation is as follows: "MOCA is probably carcinogenic to humans" and "[ $\mathrm{t}]$ here is inadequate evidence in humans for the carcinogenicity of 4,4'-methylenebis(2-chloroaniline) (MOCA)." See IARC, MONOGRAPH SERIES NO. 57, OCCUPATIONAL EXPOSURES OF HAIRDRESSERS AND BARBERS AND PERSONAL USE OF HAIR COlourants; SOME Hair Dyes, COSMETIC COlOuRANTS, Industrial Dyestuffs AND AROMATIC AMINES 271 (1993).

There is sufficient evidence in experimental animals for the carcinogenicity of 4,4'-methylenebis(2chloroaniline) (MOCA). See id.

187. See IARC, SuPPlEMENT 7, MONOGRAPH SERIES, at 150 (1987) <http://193.51.64.11/htdocs/ Monographs/Suppl7/ChloroethylNitrosoureas.html> ("No epidemiological study of CCNU as a single agent was available to the Working Group ...; there is sufficient evidence in animals, and CCNU is a directly-acting, bifunctional alkylating agent. On the weight of all the evidence, CCNU is probably carcinogenic to humans.").

188. See IARC, Benzidine-Based Dyes, Supplement Seven (last modified Feb. 11, 1998) <http:// 193.51.164.11/htdocs/Monographs/Suppl7/BenzidineDyes.html>. There is inadequate evidence for carcinogenicity to humans, but sufficient evidence for carcinogenicity to animals. See id. However, "[b]enzidine-based dyes are structurally related to benzidine, exposure to which is causally associated with cancer in humans, and commercial material may contain small amounts of benzidine." Id. The overall evaluation is that benzidine-related dyes are probably carcinogenic to humans. See id.

189. "The available studies [of carcinogenicity] are of insufficient quality, consistency or statistical power to permit a conclusion regarding the presence or absence of a causal association between exposure and cancer, or no data on cancer in humans are available." IARC Evaluation (last modified Jan. 5, 1999) <http://193.51.164.11/monoeval/Eval.html>.

190. See IARC, Overall Evaluation of Carcinogenicity to Humans, supra note 184; NINTH ANNUAL REPORT ON CARCINOGENS, supra note 156.

191. The case for benzidine-related dyes is assisted because of the structure-activity relationships between benzidine and benzidine-related dyes, and because of a particularly toxic metabolite that is common to both groups of substances. See IARC, MONOGRAPH SERIES NO. 29, SOME INDUSTRIAL CHEMICALS AND DYESTUFF, 149 (1982). For another discussion of the importance of structureactivity relationships, see Bernard D. Goldstein \& Mary S. Henifin, Reference Guide on Toxicology, in REFERENCE MANUAL ON SCIENTIFIC EVIDENCE , supra note 3, at 421.

192. See IARC, supra note 184.

193. See id. 
"other data relevant to the evaluation of carcinogenicity and its mechanisms." The additional evidence may be that the substance (1) has substantial genetic effects in relevant mammals; (2) that it has carcinogenic metabolites common to humans and animals; (3) that it belongs to a well-defined, structurally related class of agents known to cause cancer; (4) that it binds to receptors related to cancer in both humans and animals; (5) that it binds to DNA and is believed to contribute to genetic mutations; or (6) that it causes multiple tumors at multiple sites in one or more species of animals.

The EPA is prepared to classify substances as probable human carcinogens based upon animal studies, even if the evidence that a substance is carcinogenic to humans is inadequate. These are substances "likely to produce cancer in humans due to the production or anticipated production of tumors by modes of action that are relevant or assumed to be relevant to human carcinogenicity." ${ }^{195}$ This too is reliable evidence for admissibility.

Finally, consider an unusual instance, in which a defendant was convicted of murder based largely upon animal and mechanistic evidence. ${ }^{196}$ In that instance, the conclusion that the substance dimethylnitrosamine, a carcinogen, was a human liver poison was based upon acute toxicity studies in rats, inhalation studies in dogs and mice, three sets of case studies in humans (two people each), pathology evidence, some DNA studies, and extensive circumstantial evidence, but no epidemiological studies. The only human evidence was the case studies and the dead and injured people in the murder case. ${ }^{197}$

\section{Learning from Reliable Patterns of Evidence}

What can be learned from these examples? First, there are a variety of explanatory paths to a conclusion that a substance is more likely than not a human carcinogen. Different kinds of evidence taken together can support such conclusions. There is no universal inferential model. Second, each group illustrates a scientifically respectable and reliable pattern of evidence for concluding that a substance more likely than not causes or can cause cancer in humans that is supported by appropriate scientific reasoning that satisfies the Daubert criteria. ${ }^{198}$ Third, direct epidemiological data is not necessary for judging whether a substance is a certain or likely human carcinogen. Non-human evidence that is widely accepted in the scientific community is of significant probative value. Animal, in vitro, and various forms of mechanistic evidence, including struc-

194. Id.

195. Environmental Protection Agency Proposed Guidelines, supra note 159, at 17,985.

196. See Cranor et al., supra note 104, at 55-56.

197. See Renate D. Kimbrough, Pathological Changes in Human Beings Acutely Poisoned by Dimethylnitrosamine, BANBURY REPORT NO. 12; see also NITROSAMINES \& HUMAN CANCER 25-34 (Peter N. Magee ed., 1982); Ronald C. Shank \& Deborah C. Herron, Methylation of Human Liver DNA After Probable Dimethylnitrosamine Poisoning, NiTROSAMINes \& HUMAN CANCER 153-59 (Peter N. Magee ed., 1982); Berton Roueche, The Lemonade Mystery, SATURDAY EVENING Post, May-June 1982 , at 58 .

198. See Daubert v. Merrell Dow Pharms., Inc., 509 U.S. 579, 588 (1993). 
ture-activity relationships, can be particularly important, depending upon the presence of other evidence. Fourth, the scientific inferences described above, based upon combinations of studies and on the scientific reasoning, are taken from those used by the International Agency for Research on Cancer and the National Toxicology Program, and are similar to those used by the Environmental Protection Agency and the California Environmental Protection Agency, and are inferences that many toxicologists would endorse. ${ }^{199}$ Fifth, because of their standing as sound toxicological inferences, they are sufficiently reliable to satisfy the deeper rationale for exceptions to the hearsay rule, because they play such an obvious role in inferences endorsed by scientific bodies and experts in toxicology. Sixth, the evidentiary pattern utilized for each substance also suggests that, at the time these decisions were made, different kinds of evidence were critical or decisive in classifying the substance. Animal evidence was particularly important. Sometimes, surprisingly to some, it was metabolic and structure-activity evidence (for benzidine-related dyes and CCNU). Sometimes it was largely mechanistic evidence (CCNU) but a detailed mode of action that is often difficult to provide. In many cases, the combination of evidence from animals, chemical structure, and other mechanistic considerations led to a conclusion that the substance was a likely or known human carcinogen. Seventh, contrary to the Supreme Court's view in Joiner, all of the evidence in each case bears on an assessment of whether something is a likely human carcinogen. ${ }^{200}$ Thus, for courts to identify one piece of evidence as inadequate by itself to implicate a substance as toxic —or to evaluate each piece as inadequate for the ultimate conclusion-and then to suggest that the evidence as a whole is inadequate violates rules of good evidence evaluation ${ }^{201}$ and is contrary to weight-of-the-evidence procedures that are so important in the scientific evaluation of toxicants. ${ }^{202}$ Finally, patterns of evidence and lessons learned from them are easy cases because they result from consensus judgments of international or national scientific bodies or independently-reviewed judgments of agencies such as the National Toxicology Program and the EPA. These scientific conclusions are not taken from marginal scientists, charlatans, or junk scientists, yet the inference patterns are sufficiently varied to serve as a caution

199. There may be some disagreement between scientific bodies on particular substances, reflecting legitimate scientific disagreement, but they agree in broad outline on these issues. See generally Environmental Protection Agency Proposed Guidelines for Carcinogen Risk Assessment, supra note 159; IARC, Preamble to the IARC Monographs (last modified Aug. 9, 2000) <http://193.51.164.11/monoeval/ preamble.html>; Ninth Annual Report on Carcinogens, supra note 156.

200. See General Elec. Co. v. Joiner, 522 U.S. 136, 152-53 (1997) (Stevens, J., concurring in part and dissenting in part) (arguing that the majority's reliability ruling was not faithful to the statement in Daubert that "[t]the focus, of course, must be solely on principles and methodology, not on the conclusions that they generate."). Justice Stevens also argues that both the district court and the Supreme Court evaluated each scientific study as inadequate for the supporting the expert's ultimate conclusion but did not properly address Joiner's experts relying upon a weight of the evidence methodology. See id. at 153-55.

201. See LARry Wright, Practical REASONING 93-110 (1987).

202. See Environmental Protection Agency Proposed Guidelines for Carcinogen Risk Assessment, supra note 159 , at $17,981-92$. 
against overly simple reasons for rejecting evidence. Similar work should be done on neurotoxicants, reproductive toxicants, and others.

\section{E. Principles of Toxicology Underlying the Evidentiary Patterns}

In addition to the patterns of evidence that scientific bodies have endorsed, some principles of carcinogen biology and toxicology would assist judges in their review of expert testimony on general causation. These biological principles provide a foundation for the patterns of evidence and the scientific inferences just described. Just as in law, where more general principles provide reasons for drawing inferences about particular legal cases, these principles support inferences from particular biological experiments that lead to conclusions about particular substances or patterns of evidence indicating that a substance can cause human harm. Some biological principles concerning inferences from animal studies loom so large in the toxicology of carcinogens that focus on them is particularly relevant.

First, although there are readily apparent differences between laboratory animals and humans (such as size, lifespan, metabolic rate, and heterogeneity), which often receive greater attention than similarities, "experimental evidence to date certainly suggests that there are more physiologic, biochemical and metabolic similarities between laboratory animals and humans than there are differences." ${ }^{203}$

Second, "biological processes of molecular, cellular, tissue, and organ functions that control life are strikingly similar from one mammalian species to another. Such processes as sodium and potassium transport and ion regulation, energy metabolism, and DNA replication vary little in the aggregate as one moves along the phylogenetic ladder." ${ }^{204}$

Third, based upon current information, there is great similarity in the carcinogenic processes between animals and humans. ${ }^{205}$

Fourth, and more fundamentally, "the more we know about the similarities of structure and function of higher organisms at the molecular level, the more we are convinced that mechanisms of chemical toxicity are, to a large extent, identical in animals and man." ${ }^{206}$ The EPA and the Federal Judicial Center Manual on Scientific Evidence concur. ${ }^{207}$

203. Rall et al., supra note 140 , at 356.

204. Huff \& Rall, supra note 7, at 434. Significant scientific understanding of neural transmission, renal function, and cell replication and development of cancer have come from non-human species, often species far removed phylogenetically from humans. See id.

205. Some researchers make even stronger claims. For example, see James Huff, Chemicals and Cancer in Humans: First Evidence in Experimental Animals, 100 EnVTL. HEALTH PersP. 201, 204 (1993) (stating that the array and multiplicity of carcinogenic processes are virtually common among mammals, for instance between laboratory rodents and humans).

206. Id. at 204.

207. See Environmental Protection Agency Proposed Guidelines for Carcinogen Risk Assessment, supra note 159, at 17,977 ("[T]here is evidence that growth control mechanisms at the level of the cell are homologous among mammals, but there is no evidence that these mechanisms are site concordant [i.e., must be in the same tissue in rodents and humans]."); Goldstein \& Henifin, supra note 191, at 419. 
Fifth, differences in carcinogenic response can occur from one species to another $^{208}$ However, there are particular patterns of responses in animals that greatly increase the likelihood that a carcinogenic response in one mammalian species will produce a carcinogenic response in another mammalian species. ${ }^{209}$ Cross-species predictions are substantially higher for mutagens (agents that cause mutations) than nonmutagens, for substances that are toxic at low doses, ${ }^{210}$ for substances that show a dose-response relationship or reduced latency period, and for substances that induce uncommon tumor types or tumors at multiple sites and tumors in both sexes of one test species. ${ }^{211}$ "[I]f a chemical causes multiple tumors in one species it is virtually certain to increase the tumor rate in the other species as well." 212 Cross-species carcinogenic responses constitute evidence scientists utilize to help conclude that substances with these properties in animals are more likely to be carcinogenic in humans. Different exposure patterns than those utilized in the National Toxicology Program tests and mechanistic factors may modify these conclusions. ${ }^{213}$

Sixth, as Huff and Rall conclude,

[f]rom data available so far, therefore, it appears that chemicals that are carcinogenic in laboratory animals are likely to be carcinogenic in human populations and that, if appropriate studies can be performed, there is qualitative predictability. Also, there is evidence that there can be a quantitative relationship between the amount of a chemical that is carcinogenic in laboratory animals and that which is carcinogenic in human populations. ${ }^{214}$

Others, including the National Academy of Sciences, have concurred. ${ }^{215}$ Utilizing the language of rebuttable presumptions, the Academy notes that

208. For example, rats and mice differ at least $25 \%$ of the time. See George M. Gray et al., An Empirical Examination of Factors Influencing Prediction of Carcinogenic Hazard across Species, 22 REG. TOXICOLOGY \& PHARMACOLOGY 283, 284, 287 (1995) (arguing in general that a positive carcinogenic response in mice is associated with a positive carcinogenic response in rats $76 \%$ of the time, and the converse association from rats to mice is $71 \%$ (chance would produce positive response rates of $48 \%$ from mice to rats and $43 \%$ from rats to mice)).

209. See id. The elevated concordance across species for the above comparisons ranges from $84 \%$ to $98 \%$ depending upon the comparison considered, all well above the average positive predictive value of carcinogenic responses between rodents and much above chance concordance.

210. See L. Gold et al., Interspecies Extrapolation in Carcinogenesis: Prediction between Rats and Mice, 81 EnVtl. Health Perspectives 211, 211-19 (1989).

211. See Gray et al., supra note 208.

212. Id. at 288 .

213. See id. at 290

214. Huff \& Rall, supra note 7, at 437.

215. See Huff, Chemicals and Cancer in Humans, supra note 205, at 205 (quoting the NATIONAL ACADEMY OF SCIENCES, Pest Control: An Assessment of Present and Alternative Technologies, in

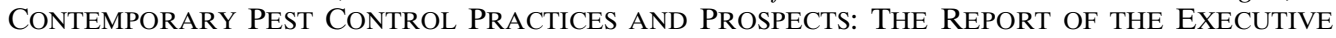
CommitTeE 66, 66-83 (1975)); see also Victor A. Fung et al., The Carcinogenesis Bioassay in Perspective: Application in Identifying Human Cancer Hazards, 103 ENVTL. HEALTH PERSP. 680, 682 (1995) (arguing that chemicals shown to unequivocally induce cancer in laboratory animals, especially in multiple species, must be considered capable of causing cancer in humans). Moreover, a group of researchers from the National Institute of Environmental Health Sciences, the University of North Carolina, the International Agency for Research on Cancer, the Linkoping University in Sweden, the National Cancer Institute, and National Institute of Occupational Safety and Health have concluded that experimental results, in particular long-term carcinogenicity tests, have proven to be valid predictors of human risk. See Tomatis et al., supra note 30, at 103. 
in the absence of countervailing evidence for the specific agent in question, it appears reasonable to assume that the life-time cancer incidence induced by chronic exposure in man can be approximated by the life-time incidence induced by similar exposure in laboratory animals at the same total dose per body weight. ${ }^{216}$

The principles of toxicology just rehearsed are the scientific analogues of rebuttable presumptions. That is, they support inferences, unless there is rigorous substance-specific evidence to the contrary, and they help make inferences reliable concerning the toxicology of carcinogens. There are exceptions to these presumptions, but they are recognized as such. In exceptional circumstances, for example, the IARC will deviate from its presumption about animal carcinogens. ${ }^{217}$ Other scientific bodies disagree with this, further illustrating scientific diversity on complex issues. ${ }^{218}$

In addition to the general principles-and contrary to what some have suggested-Huff and Rall argue that there are some reasons to believe that humans are as sensitive or more sensitive than animals to exposures from various chemicals. ${ }^{219}$ For several substances tested in animals, the animal exposures were "the same or less than" human exposures. In twenty chemotherapeutic agents, the

toxic doses were highly correlated if expressed on a dose per kilogram of body weight basis and almost identical if expressed as dose per body weight to the two-thirds power. This would suggest that humans may be up to ten times more sensitive than the typical small laboratory animal if the comparison is made on the basis of dose per kilogram of body weight.

216. Huff \& Rall supra note 7, at 437 (quoting the NATIONAL ACADEMY OF SCIENCES, supra note 215). Subsequent to this paper by Huff \& Rall, Curtis Travis published a paper that recommends that the appropriate interspecies scaling factor be the dose per body weight to the $3 / 4$ power, a value somewhat different from the Academy's scaling factor. There now appears to be a substantial consensus on Travis's point. See Curtis C. Travis, Interspecies Extrapolation of Toxic Data, in DERMAL AND INHALATION EXPOSURE AND ABSORPTION OF TOXICANTS 387-410 (R.G.M. Wang et al. eds., 1993).

IARC concurs: " $\mathrm{I}] \mathrm{t}$ is biologically plausible ... to regard agents and mixtures for which there is sufficient evidence of carcinogenicity in experimental animals as if they presented a carcinogenic risk to humans." IARC, Preamble to the IARC Monographs, Section 9 (last modified Jan. 5, 1999) <http:// 193.51.164.11/monoeval/StudiesAnimals.html>.

217. See Rice et al., supra note 165, at 171 (arguing that when there are consistent and convincingly negative results that a substance is not genotoxic, and by application of the most rigorous scientific criteria it is found that an agent acts by a mechanism that does not operate in humans (and some other specific conditions are found pertinent to particular substances), then an animal carcinogen may be judged as not classifiable as to human carcinogenicity).

218. The California EPA disagrees with some of the reclassifications of animal carcinogens on the basis of mechanistic information and would continue to regard them as potential human carcinogens. Interview with Lauren Zeise, Ph.D., Chief, Reproductive and Cancer Hazard Assessment, California EPA (Sept. 20, 2000).

219. See Huff \& Rall, supra note 7, at 439.

In an experimental analysis of the short-term toxicity of more than 20 cancer chemotherapeutic agents in laboratory animals and humans, it was shown that the toxic doses were highly correlated if expressed on a dose per kilogram or body weight basis and almost identical if expressed as dose per body weight to the two-thirds power.

Id. (citing E.J. Freireich et al., Quantitative Comparison of Toxicity of Anticancer Agents in Mouse, Rat, Hamster, Dog, Monkey and Man, 50 CANCER CHEMOTHER. ReP. 199 (1990)).

220. Id. For a qualifier concerning the particular scaling factor, see Travis, supra note 216.

Smaller animals tend to metabolize and excrete foreign organic chemicals more rapidly than do larger mammals; therefore, higher body burdens develop in humans over the years than 
Further, humans are genetically much more varied than animals bred for laboratory experiments. ${ }^{221}$ This raises two points. First, the human population with its greater genetic, metabolic, and other individual variability exhibits a wider range of responses to toxic exposures than other mammalian species uniformly bred for experimental purposes. Some individuals will be more or less resistant than others. For example, people with ataxia telangiectasia, a DNA repair disorder, are highly susceptible to ionizing radiation exposure. ${ }^{222}$ Persons with xeroderma pigmentosum, another DNA repair disorder, are highly susceptible to ultraviolet radiation. ${ }^{223}$ Those who are slow acetylators, meaning slow to metabolize certain compounds through acetylation, are at higher risk for lupus from exposure to hydralazine or procainimide, while those who are rapid acetylators are believed to be at higher risk of carcinogenesis from heterocyclic amines. $^{224}$ It may be difficult to know in advance in particular cases who has greater or lesser susceptibility to these or similar conditions, but the fact of widely differing susceptibility should caution judges against being too quick to reject evidence of a toxic effect in a given individual.

In making admissibility decisions, courts should allow for interindividual variability and for the possibility of greater sensitivity of some people to a toxic exposure. Indeed, the "eggshell skull" principle, part of tort law for more than one hundred years, ${ }^{225}$ specifically recognizes that if a person's legitimate interests have been wrongly invaded by a tortfeasor, the defendant takes the victim as he finds him. ${ }^{226}$ The principle appears to be that when there are wrongful in-

develop in mice and rats in a 2-year experimental period .... Because chemically induced cancer is viewed as originating in one or a few cells, it is relevant that a human has hundreds of times more susceptible cells than does a mouse or a rat .... [T] he cells of small animals turn over or replicate themselves at perhaps twice the rate of cells in larger mammals such as humans, and latent periods are longer in large animals. The human life span, however, is about 30 to 35 times that of the mouse or rat and this may make humans more susceptible.

Huff \& Rall, supra note 7, at 439-40.

221. See Dale Hattis \& K. Barlow, Human Interindividual Variability in Cancer Risks: Technical and Management Challenges, 2 HeAlTH \& ECOLOGICAL RISK AssESSMENT, 194 (1996); Dale Hattis, Variability in Susceptibility: How Big, How Often, for what Responses to What Agents?, 4 ENVTL. Toxicology AND Pharmacology 195, 205-06 (1997); Dale Hattis et al., Distributions of Individual Susceptibility Among Humans for Toxic Effects-For What Fraction of Which Kinds of Chemicals and Effects Does the Traditional 10-Fold Factor Provide How Much Protection?, 895 ANNALS N.Y. ACAD. SCI., 286 (1999); S. Venitt, Mechanisms of Carcinogenesis and Individual Susceptibility to Cancer, 40 Clin. CHEM. 1421 (1994).

222. See Michael Swift et al., Incidence of Cancer in 161 Families Affected by Ataxia-Telangiectasia, 325 NEW ENG. J. MED. 1831, 1831-36 (1991).

223. See Allan C. Halpern \& J.F. Altman, Genetic Predisposition to Skin Cancer, 11 CURRENT OP. ONCOLOGY 132 (1999).

224. See John Timbrell, Principles of Biochemical Toxicology 136 (2000); J. Chen et al., A Prospective Study of N-Acetyltransferase Genotype, Red Meat Intake, and Risk of Colorectal Cancer, 58 CANCER RES. 3307-11 (1998); A.C. Deitz et al., N-Acetyltransferase-2 Genetic Polymorphism, WellDone Meat Intake, and Breast Cancer Risk Among Postmenopausal Women, 9 CANCER EPIDEMIOL. BIOMARKERS PREV. 905-10 (2000).

225. See KeEton ET AL., supra note 55, at 291-92.

226. See Maurer v. United States, 668 F.2d 98, 99-100 (2d Cir. 1981).

It is a settled principle of tort law that when a defendant's wrongful act causes injury, he is fully liable for the resulting damage even though the injured plaintiff had a preexisting condi- 
vasions, everyone has equal standing to be protected from harm even though some have eggshell skulls, some are pregnant, some have predispositions to disease or to "loss of hair from fright." ${ }^{27}$ Thus, if some people are more sensitive to toxic exposures than other people or than animals, courts should allow for this in admitting evidence in toxic tort cases. This suggests that even if a plaintiff suffers a toxic effect at modestly lower exposure levels that is identical to a toxic effect produced at higher exposure levels, this could be considered a presumptive reason for inferring that the toxic substance contributed to plaintiff's disease. However, even if a defendant is found liable, it does not necessarily follow that a plaintiff is entitled to full compensation for her injuries because defendant has only exacerbated an existing weakness. ${ }^{228}$

VI

\section{Is THERE A NEED FOR TORT LIABILITY REFORM?}

Some courts, in implementing evidentiary reform, may be mistakenly excluding experts and reliable scientific evidence. To address this, courts need to recognize the wider range of reliable toxicological evidence that scientists utilize to conclude that substances are known or likely human toxicants or carcinogens. This would solve a number of problems mentioned above. It would permit tort law better to use the sometimes sparse but reliable scientific evidence that is available in present circumstances, and it would provide the possibility of justice for more litigants than at present. In addition, it would result in greater compatibility between current tort liability rules and the science needed to support judgments of cancer causation in toxic tort cases.

tion that made the consequences of the wrongful act more severe than they would have been Id.

for a normal victim. The defendant takes the plaintiff as he finds him.

It is as if a magic circle were drawn about the person, and one who breaks it, even by so much as a cut on the finger, becomes liable for all resulting harm to the person although it may be death. The defendant is held liable when the defendant's negligence operates upon a concealed physical condition, such as pregnancy, or a latent disease, or susceptibility to disease [psychotic or neurotic predispositions, predisposition to amnesia, ruptured disc, delirium tremens], to produce consequences which the defendant could not reasonably anticipate. The defendant is held liable for unusual results of personal injuries which are regarded as unforeseeable, such as tuberculosis, paralysis, pneumonia, heart or kidney disease, blood poisoning, cancer or the loss of hair from fright.... One of the illustrations which runs through the English cases is that of the plaintiff with the "eggshell skull," who suffers death where a normal person would have had only a bump on the head ....

KEETON ET AL., supra note 55, at 291-92.

It is important to note that there must be a wrongful invasion of interest before the eggshell skull principle can be invoked. Whether this will always be true as a result of exposure to a toxic substance is an issue that must be addressed.

227. See Ominsky v. Weinhagen \& Co., 113 Minn. 422, 423 (1911); see also Carl F. Cranor, Eggshell Skulls and Loss of Hair from Fright: Some Moral and Legal Principles that Protect Susceptible Subpopulations, 4 ENVTL. TOXICOLOGY \& PHARMACOLOGY, 239-45 (1998) (arguing that widely accepted moral principles, as well as the "egg shell skull" principle in torts provide reasons for protecting even especially susceptible seed populations).

228. See KeEton ET AL., supra note 55, at 291-92. 
Implementing such suggestions would be an improvement within the current liability rules. Even if these suggestions were fully adopted, however, they might fail to address a deeper issue: the woeful ignorance that plagues much scientific and agency knowledge of the universe of chemical substances. At present it is both possible and likely that some toxic tort cases are dismissed simply because of ignorance about a particular substance and its properties, leaving wrongfully injured plaintiffs without a remedy, and undermining the deterrence goal of tort law.

It will be difficult to understand whether this is a problem-apart from general assessments about extensive scientific ignorance of substances-or how extensive it might be. There is a concern, however, that tort law itself lacks adequate liability rules to motivate firms that manufacture and use potentially toxic substances to take steps to properly test them. Thus, at present it appears that there may be much less testing and review of the safety of substances than different or additional liability rules might produce. The present causation element required of tort liability (together with substantial ignorance about toxic substances) creates a barrier to recovery in torts and "creates incentives on the part of corporations not to know and not to disclose."229 Moreover, judicial review of the science needed to establish causation is a task with which judges may be quite uncomfortable. In light of these considerations, current law might be inadequate in the face of scientific ignorance of the properties of possible toxicants. In short, tort liability rules may need to be modified in order for tort law better to address the extensive ignorance about the substances registered in commerce. $^{230}$

Professor Berger has made such a proposal:

[L]iability in negligence [should] be imposed for failure to provide substantial information relating to risk and proof that the failure caused plaintiff's injury would not be required; defendants would be relieved of liability for injuries caused by exposure to their products, provided that they had met the required standard of care for developing and disseminating information relevant to risk.

The idea would be to create "a new tort that conditions culpability on the failure to develop and disseminate significant data needed for risk assessment." ${ }^{232}$

[O]nce plaintiffs proved the manufacturers' negligence in failing to reveal substantial information highly relevant to assessing the potential risks of asbestos exposure, a prima facie case of liability would be made out for those able to substantiate exposure and ill health. Defendants should, however, be entitled to two special defenses: ... (1) to prove in general that certain adverse health reactions could not plausibly arise from exposure to defendant's product, or (2) to reduce damages by proof that a particular plaintiff's injury is attributable or partly attributable to another cause, such as smoking. Defendant should bear the burden of persuasion on these issues. ${ }^{233}$

229. Berger, supra note 2, at 2119.

230. See CRANOR, supra note 81 , at $91-151$.

231. Berger, supra note 2 , at 2143.

232. Id. at 2140 .

233. Id. at 2144-45. 
There are other possibilities. One strategy might be to shift the burden of proof once "plaintiffs have made a specified threshold showing of causation." Another might be somewhat analogous to duties to be informed about hazards and duties toward others in product liability cases. ${ }^{235}$ At this juncture, the point is not to propose a specific alternative, but to sketch the types of legal modifications that should be explored in order

to induce corporations to engage in far more scientific research when it matters-not to win lawsuits but to protect society against the risks posed by their products. The proper role for scientists with regard to toxic substances should be to provide needed information about possible latent defects, not to cast deciding votes on liability because causation has been made a surrogate for morally responsible corporate behavior. $^{236}$

234. Michael H. Gottesman, From Barefoot to Daubert to Joiner: Triple Play or Double Error?, 40 ARIZ. L. REV. 753, 779 (1998). This point was also suggested by Francis McGovern of the Duke University School of Law. Professor Gottesman suggests that

if plaintiffs showed a specified number of epidemiological studies in which there were elevated incidences of cancer, coupled with evidence that the substance is causing cancer in animal studies and/or evidence that the chemical composition of the substance is similar to other substances known to be carcinogenic, a presumption of causation would arise .... Id. at 779 .

His scientific requirements appear to endorse an epidemiological threshold and thus are too strong. A better principle would suggest, in the spirit of this article, that if plaintiffs could present a pattern of evidence similar to other patterns of evidence that had implicated substances as likely human carcinogens, then a presumption of causation would arise. The virtue of the alternative proposal is that it is neutral between different patterns of evidence, different explanatory paths to the same conclusion, and it does not require an epidemiological threshold.

235. Gregory Keating of the University of Southern California Law School suggested this point. For a more specific articulation, see Feldman v. Lederle Labs., 479 A.2d 374, 386 (N.J. 1984) (holding that drug companies will be negligent if they have failed to warn of a risk of which they knew "or should ... have known ... given the scientific, technological, and other information available when the product was distributed; . . . in other words, ... actual or constructive knowledge of the danger").

Constructive knowledge embraces knowledge that should have been known based on information that was reasonably available or obtainable and should have alerted a reasonably prudent person to act. Put another way, would a person of reasonable intelligence or of the superior expertise of the defendant charged with such knowledge conclude that defendant should have alerted the consuming public?

Id. at 386 .

"Further, a manufacturer is held to the standard of an expert in the field. A manufacturer should keep abreast of scientific advances ...." Id.

"Thus, for example, if a substantial number of doctors or consumers had complained to a drug manufacturer of an untoward effect of a drug, that would have constituted sufficient information requiring a warning." Id. at 387 (citing Skill v. Martinez, 91 F.R.D. 498, 514 (D.N.J. 1981), aff'd on other grounds, 677 F.2d 368 (3d Cir. 1982) (jury finding in products liability action for plaintiff upheld because "sufficient knowledge existed, in the form of articles of preliminary findings by two leading researchers in the field, of danger inherent in taking birth-control pill while smoking to warrant drug manufacturer's giving proper warning)); see McKee v. Moore, 648 P.2d 21, 24 (Okla. 1982) (finding that the duty to warn requires prescription drug manufacturer to maintain current information "gleaned from research, adverse reaction reports, scientific literature and other available methods").

236. Berger, supra note 2, at 2152. 


\section{VII}

\section{CONCLUSION}

As a first step to preserving the central aims of tort law, courts will need to recognize the wide variety of respectable, reliable patterns of evidence on which scientists themselves rely for drawing inferences about the toxicity of substances. The patterns of inferences presented above for carcinogens, arguably one of the most difficult of toxic substances with which scientists and courts must deal, serve as examples of some of the variety of inference patterns utilized in the scientific community. Courts, recognizing a wider variety of inferences, would then be able to better assess the sparse scientific evidence that is typically available.

This idea may not, however, do enough to help remedy the enormous scientific ignorance about the universe of chemical substances that are currently used in commerce, with more continuously being added. Consequently, courts may need to take further steps to address the woeful ignorance about the chemical universe. This may necessitate changes in the liability rules.

If scientific knowledge about the toxicity of a substance in humans could be accumulated instantaneously, there would not be the concern that science delayed or incomplete was justice denied. If scientists could instantaneously have the best human evidence of toxicity, they would not need to piece together animal, mechanistic, genetic, structure-activity, and other inferential evidence. If diseases could be identified at an early stage, left their signatures, or did not have long latency periods, there might be a lesser need for various kinds of nonhuman evidence. However, given the nature of the biological world and the recognition that science in its current stage of development does not have such capabilities, courts must recognize this and utilize scientifically reliable patterns of evidence that will permit plaintiffs to receive just treatment in tort cases. If this is not done or it is not adequate, more fundamental solutions to these issues will need to be found. 